Hydrol. Earth Syst. Sci. Discuss., 6, 5937-5976, 2009 www.hydrol-earth-syst-sci-discuss.net/6/5937/2009/ (C) Author(s) 2009. This work is distributed under the Creative Commons Attribution 3.0 License.
Hydrology and Earth System Sciences Discussions

Papers published in Hydrology and Earth System Sciences Discussions are under open-access review for the journal Hydrology and Earth System Sciences

\title{
Recent floods in the Middle Ebro River, Spain: hydrometeorological aspects and floodplain management
}

\author{
S. Domenech ${ }^{1}$, F. Espejo ${ }^{2}$, A. Ollero ${ }^{3}$, and M. Sánchez-Fabre ${ }^{3}$ \\ ${ }^{1}$ U.T.E. Ebro Basin Hydrological Information, Zaragoza, Spain \\ ${ }^{2}$ State Meteorological Agency, Aragon Regional Office, Zaragoza, Spain \\ ${ }^{3}$ Dept. of Geography and Land Management, University of Zaragoza, Spain
}

Received: 28 July 2009 - Accepted: 25 August 2009 - Published: 17 September 2009

Correspondence to: A. Ollero (aollero@unizar.es)

Published by Copernicus Publications on behalf of the European Geosciences Union.

\section{HESSD}

6, 5937-5976, 2009

Recent floods in the Middle Ebro River, Spain

S. Domenech et al.

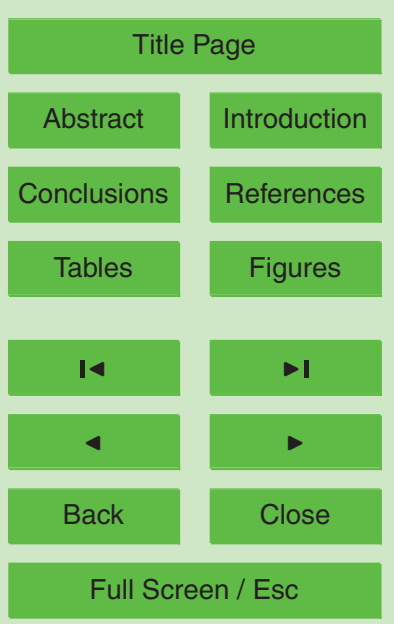

Printer-friendly Version

Interactive Discussion 


\section{Abstract}

The Ebro River has the largest Mediterranean basin in the Iberian Peninsula and the third one by surface among those of the Mediterranean Sea. The middle stretch of this river is especially interesting because it constitutes a very economically important axis 5 of population in a semi-arid environment context. Flooding processes are common in the Middle Ebro River, but the combination among decrease of discharges, dam construction and expansion and reinforcement of defences created an unusually quiet period as regards flooding events during the last quarter of the previous century. Nevertheless, with the turn of the century it seems that the Middle Ebro River has entered into new dynamics, with bigger and more frequent floods, the appearance of which has changed its seasonal nature. The most relevant examples are those of February 2003 and March-April 2007. The present paper examines these recent trends and discusses their possible causes from the points of view of hydro-meteorology, flood management through the use of reservoirs, and floodplain management. The conse15 quences of recent floods in the Middle Ebro River have reopened the debate about possible risk management measures.

\section{Introduction, antecedents and objectives}

River floods are extreme episodes necessary for the adequate functioning of rivers and their associated ecosystems. However, riparian societies do not coexist in harmony with floods, but they suffer more and more damage due to their having increasing interests in the floodable spaces. In developed countries and plain rivers, such as the case studied, there are currently planning mechanisms and safety systems enough so as not to turn a flood into a drama, but into an event that is beneficial to the river and to citizenship education.

25 Over the last two decades a line of research on fluvial systems has been developed in the Ebro basin territory. One of its work axes is made up of environmental and risk
HESSD

6, 5937-5976, 2009

\section{Recent floods in the Middle Ebro River, Spain}

S. Domenech et al.

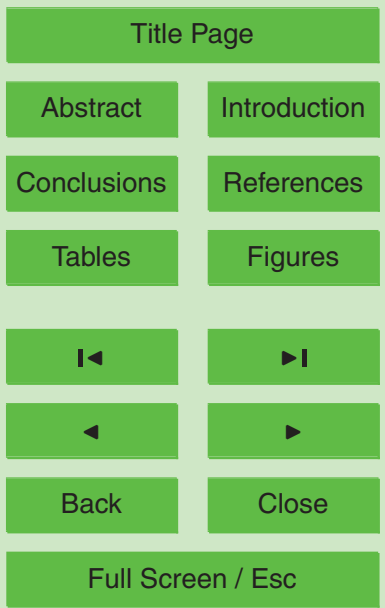

Printer-friendly Version

Interactive Discussion 
problems in the Middle Ebro River and the quest for mitigation and land management solutions (Ollero, 2000, 2007a,b; Ureña and Ollero, 2001; Ollero et al., 2004a; Espejo, 2007, 2008a,b).

While the absence of flood events has been a characteristic during the last two 5 decades of the 20th century, the first years of the 21st century have again experienced the previous frequency of high water events. Among them, those corresponding to 2003 and 2007 stand out, the first one due to the remarkable floods associated and the second one due to the complexity of the hydrometeorological process. In addition, these high water episodes have been very illustrative not only because of their mag10 nitude, but mainly because of their management. In this regard, the new resources of the Ebro Basin Authority (Confederación Hidrográfica del Ebro, or $\mathrm{CHE}$ ) for the follow up of high waters and for the decision making process are very helpful, very specially the Automatic Hydrological Information System (SAIH-Ebro), as well as the systematic use of flights in order to analyze the extension and characteristics of the flooded area.

As a result of this management needs, the 2007/60/CE Directive of the 23 October, relative to the evaluation and flood risk management was passed. This directive clearly establishes that floods are natural events that cannot be avoided, that some human activities and the climate change are increasing their frequency and their negative impact and that rivers have to be given more space, as far as possible restoring the floodplains. Through this regulation, member states have to carry out a preliminary flood risk assessment before December 2011, have to make flood risk maps before December 2013 and have to implement risk management plans before December 2015. This regulation also indicates that risk mitigation actions have to abide by the principles of the Water Framework Directive (2000/60/CE).

A lot of interest has been raised in scientific literature by flash-floods, rather than by generalized high water episodes in large fluvial systems (García Ruiz et al., 1996; Riosalido et al., 1998; Ogden et al., 2000; Gaume et al., 2004; Anquetin et al., 2005; Norbiato et al., 2007) maybe due to the difficulty in predicting and managing them. These are hydrological phenomena of a torrential nature and very sudden, which is the
HESSD

6, 5937-5976, 2009

\section{Recent floods in the Middle Ebro River, Spain}

S. Domenech et al.

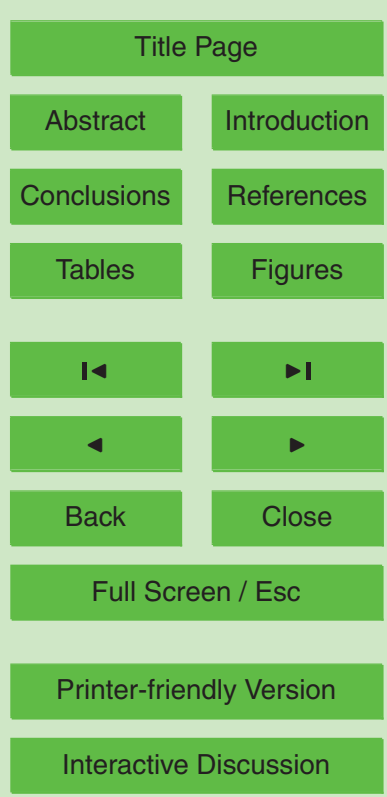


reason why their geomorphological consequences are one of the most important objectives of these studies (Arnaud-Fassetta et al., 2005). Getting to know the behaviour of the fluvial system in case of intense precipitation is key to risk management (Del Valle, 2002), and much more in such places where there is a high degree of exposure 5 of the population, as it can happen in active alluvial fans in mountain areas (Ayala, 2002; Domenech, 2008) or next to intermittent flow watercourses (Domenech, 2006).

Today, the management and river basin analysis approaches have diversified so much that lines of research have been created aimed at assessing the changes in hydrological regimes (Martínez Santa-María and Fernández Yuste, 2006), analyzing 10 the anthropic alterations in large rivers (Cabezas et al., 2009), the evolution of surface water resources (García Ruiz et al., 2001) or the large scale effects that climate change can introduce in hydrological patterns and basins (Christensen and Lettenmaier, 2007; Bates et al., 2008).

Only in some cases a few lines of research have been developed that are linked 15 to the knowledge of high water episodes in large systems with a planning or a land management nature (Carmona and Ruiz Pérez, 2000; Romero and Maurandi, 2000; Vallejo, 2000; Ibisate et al., 2000; Ratto et al., 2003; Bescós, 2003; Ibisate, 2004; Bescós and Camarasa, 2004; Arduino et al., 2005; Rabuffetti and Barbero, 2005). The development of both flood risk mapping and hydrometeorological forecast models has represented a breakthrough in flood prevention (Díez Herrero et al., 2006, 2008; Rabuffetti and Milelli, 2005; Bartholmes and Todini, 2005; Gouweleeuw et al., 2005; Kobold and Sušelj, 2005; Rebora et al., 2006).

In this line, this article is designed to analyze the behaviour and the atmospheric causes of the recent high waters of the Middle Ebro River, as well as their consequences, verifying if they are experiencing trend changes and assessing the role of hydrological management of the basin and the management of the floodplain.
HESSD

6, 5937-5976, 2009

\section{Recent floods in the Middle Ebro River, Spain}

S. Domenech et al.

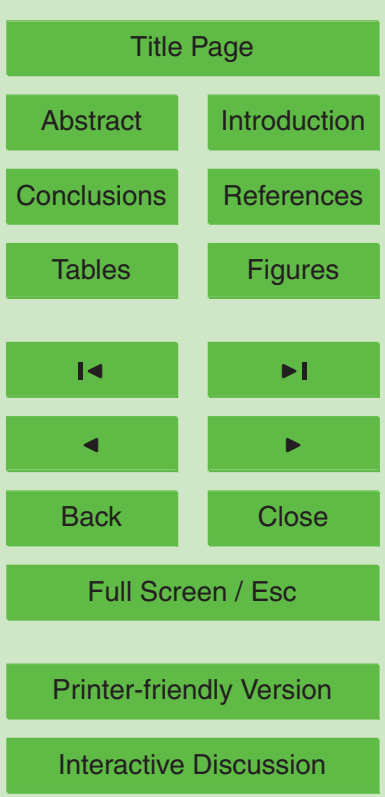




\section{Area of study}

With a 930-km-long channel, the Ebro is the largest Mediterranean river of the Iberian Peninsula and its $85000-\mathrm{km}^{2}$-basin is the third one in surface of the Mediterranean. Its average contribution, of some $14 \mathrm{~km}^{3} / \mathrm{yr}$, represents almost $4 \%$ of the total Mediter5 ranean basin contributions. The Middle Ebro River (Fig. 1) presents a meandering channel with a very low slope. The average width of the floodplain is $3.2 \mathrm{~km}$, having a maximum width of $6 \mathrm{~km}$. The mean sinuosity index is 1.505 and the average channel slope is $0.67 \mathrm{~m} / \mathrm{km}$. It has been a very dynamic course, with meander cut-offs and channel morphology changes, up to the eighties of the 20th century, when the 10 defences have finished by stabilising the banks (Ollero, 1992). Although the riparian corridor has been reduced in its surface, currently limiting itself to $40 \%$ of its 1950 extension, it keeps some high ecological value forests and has discontinuous protection figures.

The Middle Ebro River presents a pluvio-nival hydrological regime, with a maximum 15 in winter (February), and low water level in summer. Along the river channel a progressive loss of specific discharge is recorded (Fig. 2). In the Middle Ebro River stands out the remarkable increase of discharge contributed from the Aragon River basin, which drains the Western Pyrenees.

The interannual irregularity, expressed in function of the coefficient of irregularity -the maximum mean discharge divided by the minimum one in a series of years- of the Middle Ebro River is remarkable, with values between 6 and 7. In most of the years during the decades of the thirties, the sixties and the seventies, the contributions exceeded the mean value for the whole period, while during the decades of the twenties, the forties and the nineties the mean annual discharge was surpassed only occasionally. 25 Since the sixties there has been a clear decreasing trend in the contributions, especially acute during the eighties and nineties, which seems to have changed during the years of the 21st century that have gone by (Fig. 3).

\section{HESSD}

6, 5937-5976, 2009

\section{Recent floods in the Middle Ebro River, Spain}

S. Domenech et al.

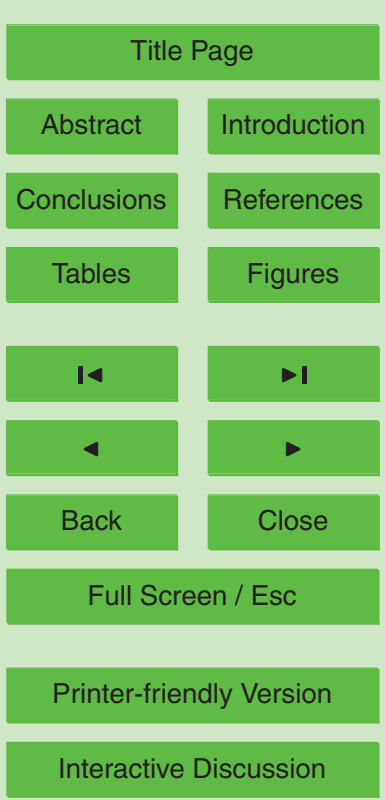




\section{Methodology}

The methodology followed in the research pools together hydrometeorological and historical data. Thus, for the analysis of past flood events discharge data and graphic documentation are used, so that the situation of these events can be gathered from

5 documentary sources (written press, records...). The Middle Ebro high water events in the basin context have always been well documented when they affected large populated areas, like Tudela or Zaragoza (Comisión Nacional de Protección Civil, 1985; Ollero, 1992). Currently, thanks to the real-time discharge gauging station of the SAIHEbro not only is it possible to know the high water process with the discharges being recorded at every $15 \mathrm{~min}$, but also to follow it in real time, with the associated advantages when it comes to managing both high waters and risk for the population. This analysis has been carried out mainly using the data of Zaragoza gauging station, located at the heart of the Middle Ebro River. For some high water events, data from the gauging stations at Mendavia and Castejón, located upstream, have been used too.

On the other hand, the existence of long series of daily data in some gauging stations has allowed to analyze the monthly, seasonal and yearly trend of the mean daily discharges over the last $100 \mathrm{yr}$. This study has been carried out both through specific statistical techniques such as bivariate correlation and through the number of occasions in which certain high water thresholds are exceeded (three, five and ten times the mean annual discharge value); this not only enables us to know the evolution of the number of days per year in which the average discharge represents a high water event, but also the changes that have been produced in its monthly or seasonal distribution.

The study of the atmospheric processes that cause fluvial high waters has a problem, which is the heterogeneity of the amount of information available with a sufficient number of statistical episodes. It is obvious that the older the situation the lesser meteorological data to accurately describe them, particularly as for extensive pressure and temperature data that enable a detailed synoptic analysis. On the contrary, a catchment such as the Ebro's has a good climatological (precipitation) and hydrological (dis-

HESSD

6, 5937-5976, 2009

\section{Recent floods in the Middle Ebro River, Spain}

S. Domenech et al.

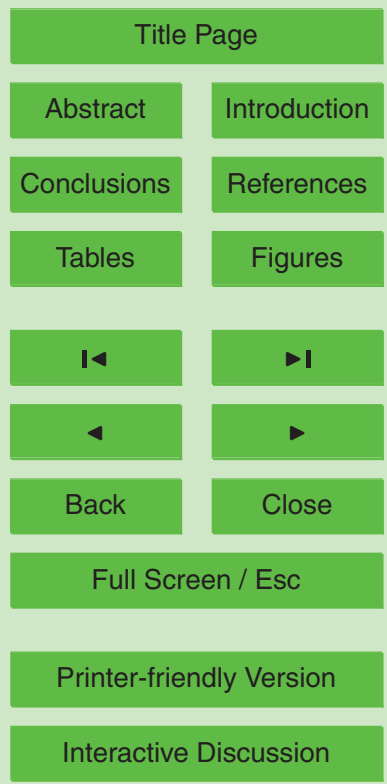

Interactive Discussion 
charge) data coverage since the first decades of the 20th century.

The development of techniques such as the numerical models of the atmosphere and the Geographic Information Systems (GIS) help solve this problem, as well as the availability of technologies such as the meteorological satellites, which enable a con5 tinuous observation with the adequate scale. The reanalysis models use old data to analyze again the status of the atmosphere of previous times, which casts a very clear light on the processes that have triggered high waters for the last fifty years. The ERA40 model of the ECMWF has been used for the analysis of the atmospheric situations causing high water events in the Ebro basin (Uppala et al., 2005). The study of the sit10 uations by means of reanalysis allows the homogenization of information and analysis techniques of situations very distant in terms of time. On the other hand, GIS have facilitated the massive use of old climatological data generating continuous precipitation maps. Another complementary product, satellite imaging, has been used to synthesize currently available information and to increase the information that has been available

\section{Results: analysis of the Middle Ebro high water events}

\subsection{Hydrometeorological aspects and classification}

The flooding processes affecting the Ebro Basin are as varied as diverse are the scopes of each of the basins of its tributaries. However, it is possible to make some generalizations considering the processes affecting large sectors of the basin, like for instance the areas located at the left bank (North) or at the right bank (South) of the main course. Another possible classification of high water processes is according those episodes affecting the tributaries at the headwaters (especially in the Cantabrian Range and the Western Pyrenees areas) and those affecting the tributaries at more Mediterranean environments (Eastern Pyrenees and areas at the SE of the basin). There is a clear difference between the meteorological origin of high water processes in the first area

HESSD

6, 5937-5976, 2009

\section{Recent floods in the Middle Ebro River, Spain}

S. Domenech et al.

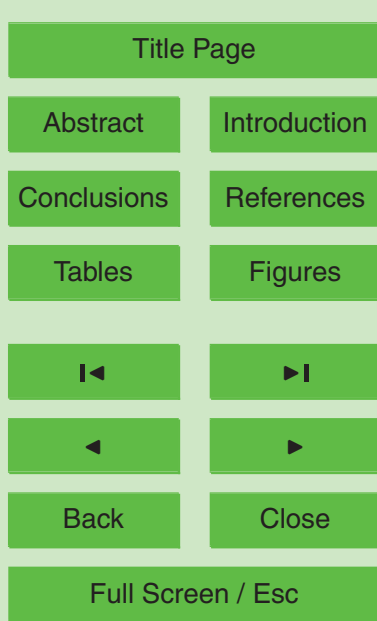

Printer-friendly Version

Interactive Discussion 
(here called upper sector) and the ones in the second area (referred to as lower sector) (Espejo, 2008b).

At the upper sector of the basin, high waters are often produced by long wavelength stationary troughs in the middle and high atmospheric levels that mean a direct influ5 ence of the NW circulation linked to the polar jet on the NW end of the basin. These troughs produce heavy precipitation events (some $250 \mathrm{~mm}$ or more) on the Cantabrian watershed and the Western Pyrenees in periods of time that may vary from one to two weeks. This type of high water event occurs mainly during winter months or at the beginning of spring (December-first days of April) and the snow precipitation processes 10 in middle or low heights and their subsequent melting tend to play a relevant role in the development of high water events.

High water events mainly affecting the so-called lower sector of the basin can have various meteorological origins. On the one hand, those episodes having impacts on larger extensions of this sector are originated by cyclonic circulations that may reach 15 the surface or not. They can accumulate amounts of about $500 \mathrm{~mm}$ in the headwaters of some sub-basins - especially the Cinca River sub-basin at the NE or the Guadalope one at the SE - in episodes typically lasting one week or less. This type of high water is more frequent in equinoctial seasons: spring - with a tendency to affect the areas to the $\mathrm{W}$ of this sector - and autumn - usually concerning the eastern half of the lower sector. Finally, events of a predominantly local nature and with flash-flood characteristics can occur mainly in summer, usually affecting the lower sector of the basin, its meteorological origin lying in convective systems.

Therefore, the situations affecting more frequently the area of study and producing floods in the Middle Ebro are the above-mentioned winter situations - of the upper 25 sector - and the equinoctial situations - mainly in spring - when they tend to have an effect on more extensive areas of the upper sector. In occasions, like in 2007, there are hybridizations and transitions between both types of high water in long-term episodes. Summer situations produce local flash-floods, but it is very difficult that they have a repercussion in the main natural "drainpipe", i.e., the Ebro River.

HESSD

6, 5937-5976, 2009

\section{Recent floods in the Middle Ebro River, Spain}

S. Domenech et al.

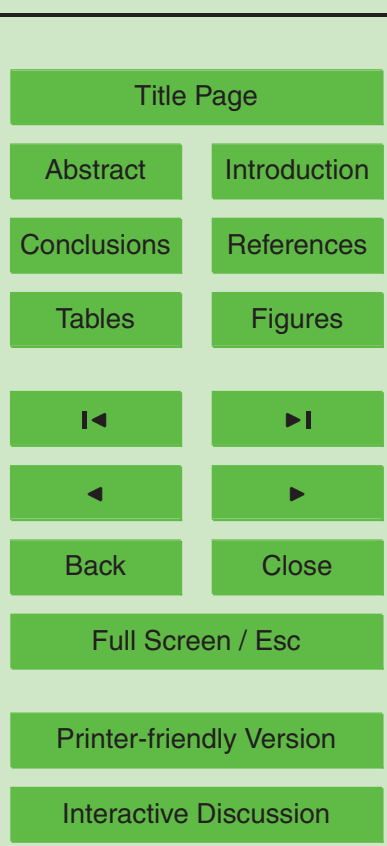




\subsection{Main events up to the year 2000}

High waters are frequent in the middle course of the Ebro River. There are documents on remarkable events since the Roman domination times (Comisión Nacional de Protección Civil, 1985). The most important processes took place in February 1643, 5 October 1787, January 1871, March 1930 and October 1937.

From 1945 discharge data in Zaragoza gauging station are more reliable. A dozen extraordinary high water events have been recorded ever since, the instant maxima of which are shown in Table 1. January 1961 high water was the most important one of the 20th century, with a return period of $84 \mathrm{yr}$ in Zaragoza gauging station. In

10 a great many areas it flooded the whole floodplain, causing huge economic losses. This flooding became the starting point of a systematic process to build bank defences (ripraps and breakwaters) and dikes along the whole river (Ollero, 1992). Table 1 shows the absence of relevant high water events in the Ebro River after those of February 1978 and December 1980 and up to the end of the 20th century.

\section{$15 \quad 4.3$ Recent flooding of the Ebro River}

Over the 21st century years that have already passed, various high water events of different magnitudes have been observed in the Middle Ebro, the most important of which being the February 2003 one, unique because the Ebro discharge in its way through Zaragoza multiplied by more than ten the value of the mean annual discharge. The March-April 2007 high water almost reached this threshold. Both are analyzed in detail below. Together with the 2007 high water above-mentioned, six other episodes reached discharge levels that multiplied by five the mean annual discharge, the 2008 one being especially significant as it took place during May and June, months in which there are hardly any events of this nature recorded.

Finally, eight new high water events have presented discharges that multiply by three the Ebro River mean annual discharge at Zaragoza gauging station. All this means that, taking as a high water threshold a discharge that at least triples the mean annual dis-

HESSD

6, 5937-5976, 2009

\section{Recent floods in the Middle Ebro River, Spain}

S. Domenech et al.

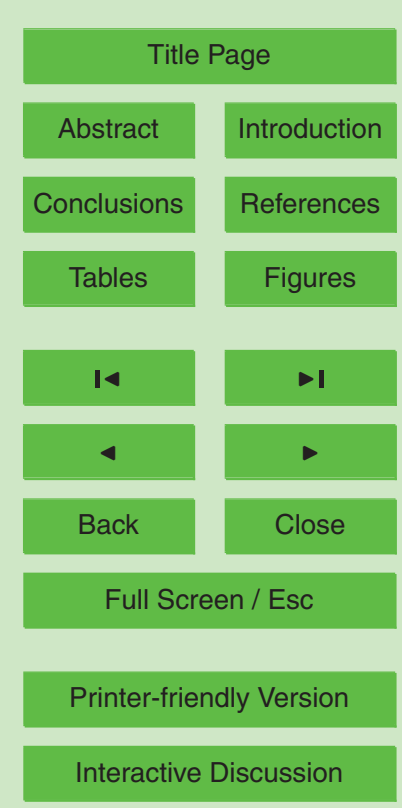


charge, 16 high water events have been recorded during the eight hydrological year's period between $2000 / 2001$ and $2007 / 2008$, which represents a remarkable mean ratio of two high water events per year.

There have been high water events in every year, 2004 and 2008 standing out with 5 three events recorded and 2001, 2003 and 2006 with two. By months it is remarkable that in March high water discharges were reached in six occasions, four in May and three both in April and in January. The distribution shown in Fig. 4 is obtained considering all the days in which the mean discharge multiplies by three, five and a minimum of ten times the mean annual discharge. The repetition of the discharge increase dur10 ing March can be observed in this figure and, above all, the strong seasonal nature of high water events, concentrated during the beginning of the 21 st century in winter and spring and almost totally nonexistent in autumn and summer.

\subsubsection{The February 2003 flood}

This event had its origin in precipitations that were not especially intense but prolonged, 15 favouring the accumulation of snow and its subsequent melting during the last days of January and the beginning of February. The said precipitations were more intense in the NW sector of the basin, specifically in the basins of the Zadorra, Ega, Arga and Aragón rivers, exceeding 40 and even $50 \mathrm{~mm}$ in $24 \mathrm{~h}$ in different observatories (Ollero et al., 2004b).

20 The situation causing this high water and the subsequent flood event is clearly a winter one (Fig. 5, left) with a deep trough at high levels that forced the inflow of maritime polar air over the NW sector of the basin and the subsequent associated frontal passage. When its continuous influence stopped, it gave way to a quick melting of the snow precipitations produced in relatively low levels, which then joined the run-offs coming 25 from the abundant previous rainfall. In addition to the meteorological causes, the water withdrawal carried out in Ullibarri-Gamboa reservoir, in the Zadorra River, contributed to increase the discharge maximum values reached during this event (Ibisate, 2004).

As the flooding progressed, the Ebro River reached high discharge volumes at all the 5946
HESSD

6, 5937-5976, 2009

\section{Recent floods in the Middle Ebro River, Spain}

S. Domenech et al.

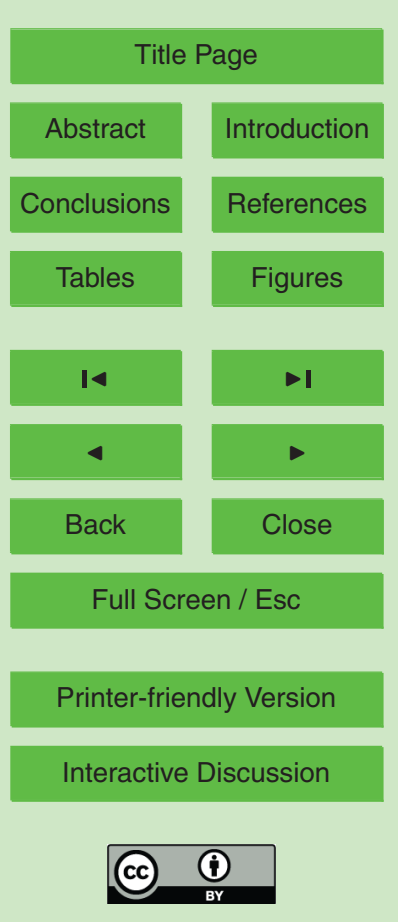


gauging stations upstream and at its middle course. The flood peaks reached historical values at Miranda de Ebro, $1430 \mathrm{~m}^{3} / \mathrm{s}$; Mendavia, $2152.4 \mathrm{~m}^{3} / \mathrm{s}$; Castejón, $3320 \mathrm{~m}^{3} / \mathrm{s}$ and Zaragoza, $2988 \mathrm{~m}^{3} / \mathrm{s}$. For the first time it was possible to follow an extraordinary flood event in real time through the information offered in the web page of the SAIH-

5 Ebro. The hydrograph (Fig. 6) reflects its characteristics: a secondary peak, after which the flow decreases a little, starting immediately afterwards a fast rising curve which leads to the maxima pointed out; the falling curve proves the high speed in flow decrease. At Zaragoza there are two peculiarities: the flow increases at relatively lower speed and the peak discharge remains at very similar levels for $15 \mathrm{~h}$.

The flood waves between Castejón and Zaragoza flow slowly, taking an average of $31 \mathrm{~h}$ in covering the distance between both gauging stations. At Zaragoza gauging station the peak discharge is on average $173.3 \mathrm{~m}^{3} / \mathrm{s}$ lower than that of Castejón in ordinary high waters, and $383.4 \mathrm{~m}^{3} / \mathrm{s}$ lower in extraordinary ones (Ollero, 1992). In the February 2003 event, the discharge peak moved in a much slower way than 15

usual, taking $72 \mathrm{~h}$ to cover the same distance. The peak discharge reduction between both gauging stations due to natural alleviation because of flooding was, in this case, $332 \mathrm{~m}^{3} / \mathrm{s}$. The February 2003 high water can be considered as an extraordinary event, being the most important one of all the events recorded at Zaragoza since 1978. Applying Gumbel's method, a return period of $10.9 \mathrm{yr}$ for Castejón (59-year series) and 20

\subsubsection{The March-April 2007 flood}

The 2007 Middle Ebro flood had its origin in the upper sector of the basin, its complexity and mixed meteorological origin with three different phases being outstanding (Espejo et al., 2008).

25 From the meteorological point of view, the event was very long, starting on the 18 March and ending on 10 April with the following phases: (i) a first phase of typical winter high water situation, associated to many precipitations in the upper sector of the basin, mostly as snow, accumulating more than $200 \mathrm{~mm}$ in the headwaters of the Arga
HESSD

6, 5937-5976, 2009

\section{Recent floods in the Middle Ebro River, Spain}

S. Domenech et al.

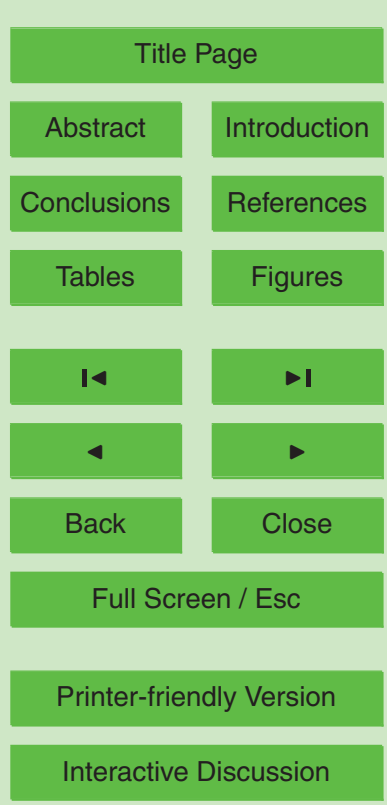


and Ebro rivers and produced by a persistent long wavelength trough; (ii) a transition phase, defined by the melting of the snow fallen over the previous days at relatively low levels; (iii) a third equinoctial high water situation, characterized by intense and prolonged precipitations generalized all over the basin - caused by a cut-off of the 5 polar circulation and the closing of stream lines forming a cut-off low, plus the snow melting run-offs (Fig. 7).

The hydrological progression of this event (Fig. 8) is defined by the presence of three peaks that follow quickly one after the other, being the last the main one, with a full correspondence with the three phases of the atmospheric situation. There was 10 another and less important high water event before, which prepared the land to favour run-offs. Due to rainfall at the basin headwaters, the flows of the Ebro and the Aragón rivers started an increase on 19 March, meaning discharge values over $450 \mathrm{~m}^{3} / \mathrm{s}$, and more or less maintaining this level up to 24 March. Later, both at Castejón and at Zaragoza gauging stations the three peaks could be clearly observed, separated by 15 sudden and very significant decreases of the discharge. The first peak was reached on 25 March at Mendavia and at Castejón, arriving at Zaragoza on 27 March.

The second peak was recorded at Mendavia, with $955.4 \mathrm{~m}^{3} / \mathrm{s}$ on 28 March, at Castejón at $2362.17 \mathrm{~m}^{3} / \mathrm{s}$ recorded at the beginning of 29 March, also recorded in the contributions of the Aragón River basin. At Zaragoza gauging station there was a peak of $1885 \mathrm{~m}^{3} / \mathrm{s}$ on the night of 30 March, $46 \mathrm{~h}$ after being recorded at Castejón.

On 2 April the Aragón and Gállego Rivers discharges (the last one a bit less) increased suddenly. As a result, the Ebro River discharge at Castejón also increased very quickly, although no discharge increase was detected at Mendavia. The Ebro River at Castejón reached a maximum peak of $2825.6 \mathrm{~m}^{3} / \mathrm{s}$ at noon on the 3 April.

25 This peak was recorded at Zaragoza late on 5 March, marking $2282.4 \mathrm{~m}^{3} / \mathrm{s}$, which means a considerable alleviation respect to the value reached at Castejón. The time lag between the peaks of these two Ebro gauging stations was practically $60 \mathrm{~h}$, almost double the usual time.

The smooth nature of the three peaks of the March-April event in Zaragoza deserves
HESSD

6, 5937-5976, 2009

\section{Recent floods in the Middle Ebro River, Spain}

S. Domenech et al.

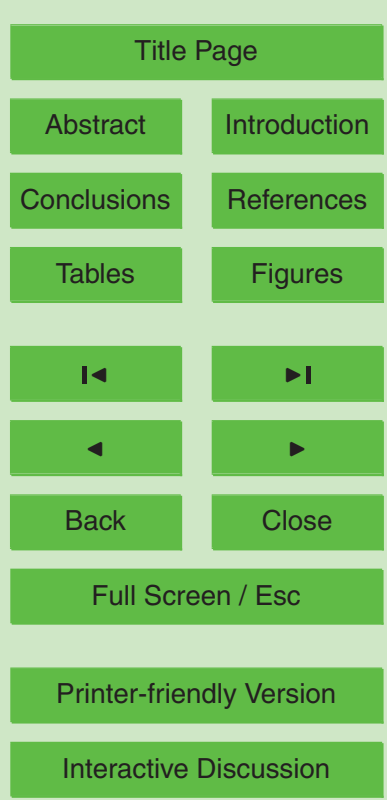


mentioning. It was due to both the natural and the induced retention carried out in the vast floodplain existing between Castejón and Zaragoza gauging stations by the Ebro Basin Authority.

However, this high water episode can be classified as ordinary and it is not one of the 5 most significant of the 20th and 21 st centuries. These events can be repeated at short intervals: the main peak discharge can be given a return period of $2.5 \mathrm{yr}$ at Mendavia, 5.6 at Castejón and 4.2 at Zaragoza.

\section{Discussion}

The above explanation on the basin and its most remarkable flooding events over the 10 last century allows us to make a series of considerations on the behaviour modifications of hydrometeorological dynamics: both hydrometeorological trends and changes in hydrological and floodplain management.

\subsection{Hydrometeorological trends}

The statistical study of the maximum annual and seasonal discharges at Zaragoza 15 gauging station shows, for the period comprised between the hydrological years 19451946 and 2007-2008, a clearly decreasing trend, observed both in the maximum annual discharge and in the maximum winter discharges (the ones causing the main floods in the Middle Ebro). In the rest of the gauging stations the trend is also negative, although it has less statistical significance. The results of the study of trends using Spearman's rho bivariate correlation, a non-parametric indicator of the relationship between the variables hydrological year and maximum discharge, (Storch et al., 1999) are shown in Table 2.

The 1960/61-2007/08 period is chosen because it is then when the main basin regulation works affecting the Middle Ebro are already in operation (Fig. 9). It is noticeable how the results are even clearer, always in the same way for the whole period, the

\section{HESSD}

6, 5937-5976, 2009

\section{Recent floods in the Middle Ebro River, Spain}

S. Domenech et al.

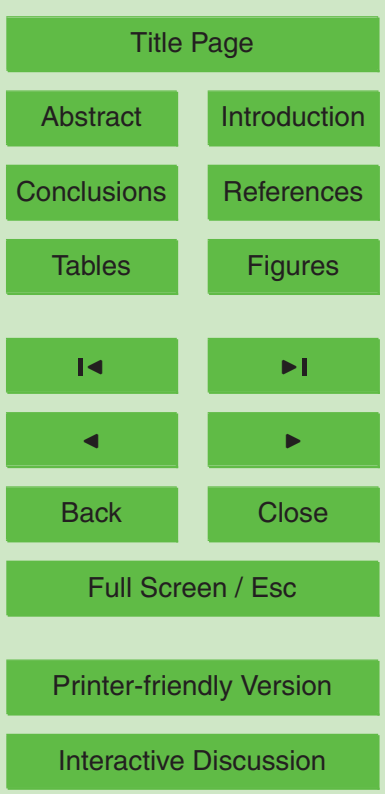

Interactive Discussion 
maximum summer discharge decrease also being statistically significant in this period.

If the last ten hydrological years are taken into consideration, the results are very different. There are no statistically significant results except for the autumn, with a strong decrease of maximum discharges at Zaragoza gauging station. Nevertheless, the cor-

5 relations are positive and both the spring maximum and the annual maximum have certain significance. Summer maximum discharges present a positive correlation and winter ones continue to show a negative correlation, although both having very little statistical significance. These last results support the theory of a recent change of trend (Fig. 10).

10 Figure 10 shows the decreasing trend of the maximum annual discharges at Zaragoza gauging station in the second half of the 20th century. This trend is linked to river regime variations, associated to a generalized decrease in the contributions, acknowledged for almost all the large basins of the Iberian Peninsula and the South and East of Europe (Gil Olcina, 2004; EEA, 2007, 2009; OSE, 2008; IPCC, 2008). These

precipitation trends involved a flow decrease in the Mediterranean basin rivers during the last third of the 20th century, which for the Ebro River meant a decrease of $2 \%$ to $10 \%$ in the mean contributions of the previous period of that century, similar or slightly higher than the decrease observed in other basins having the same characteristics, like that of the Po River (Milly et al., 2005).

20 From the mean daily data of the Ebro River at Zaragoza gauging station, corresponding to the $1913 / 14$ to $2007 / 08$ series, the number of days of every month and every hydrological year in which the mean annual discharge multiplies at least by three, five and ten times has been estimated. The aim is to find out possible trends in the frequency with which discharges that could mean a high water situation are achieved every day.

The year-to-year analysis of the number of days in which the mean discharge at least triples the Ebro River mean annual discharge at Zaragoza, expressed in Fig. 11 , proves the tremendous irregularity of the values obtained, fact closely linked to the area's total annual precipitation variability. This irregularity is already clear in the years previous to the sixties, with the particular characteristic that during that period in

HESSD

6, 5937-5976, 2009

\section{Recent floods in the Middle Ebro River, Spain}

S. Domenech et al.

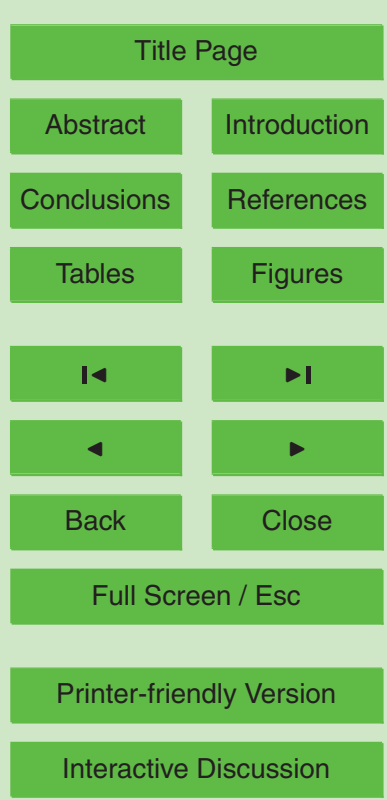

Interactive Discussion 
two out of every three years the number of days having a mean discharge that triples the mean annual discharge is lower than the mean of the whole series considered. There was a higher frequency of high water situation days during the $60 \mathrm{~s}$, starting from then on a decreasing trend that coincides with the trend presented by maximum 5 annual discharges. García Ruiz et al. (2001) have mentioned this decreasing trend in the frequency of the high water events in the high reaches of the Aragón Pyrenees tributaries of the Ebro River. During the last two years there seemed to be a certain change in the trend, but without exceeding the mean value threshold of the whole series of years. Something worth mentioning is the presence of many years since the 10 late eighties in which the number of days having a tripling of mean annual discharge is very scarce, there being no case in the periods 1988/89 and 2001/02.

In order to study the monthly distribution of days in which the mean discharge multiplies by three, five and ten times the mean annual discharge, the series has been divided into three periods: $1913 / 14$ to $1959 / 60,1960 / 61$ to $1999 / 00$ and $2000 / 01$ to $2007 / 08$ (Fig. 4). This division, as it has been said before, is due to the implementation of large dams in the sixties, as well as to the attempt to know if the evolution of the 21st century years already gone by has been continuous or singular.

In the $1913 / 14$ to $1959 / 60$ period a concentration of days with discharges considered typical of a high water situation is observed in the months of winter and at the beginning of spring. Comparing this situation with the one corresponding to the 1960/61 to $1999 / 00$ period, the most significant changes are the increase of the number of days in December and mainly January, as well as the decrease in March compared to the remarkable increase in April. All in all, the seasons having more days with high discharges are still winter and spring, the first part of winter becoming more relevant and extending up to a longer part of spring. Maybe the water withdrawal pace at reservoirs and hydraulic works has something to do with this.

During the years of the 21st century that have gone by, the situation has been rather peculiar. March is again, as it occurred in the first period considered, the month having more high water situation days, the proportion of days with mean discharges higher

\section{HESSD}

6, 5937-5976, 2009

\section{Recent floods in the Middle Ebro River, Spain}

S. Domenech et al.

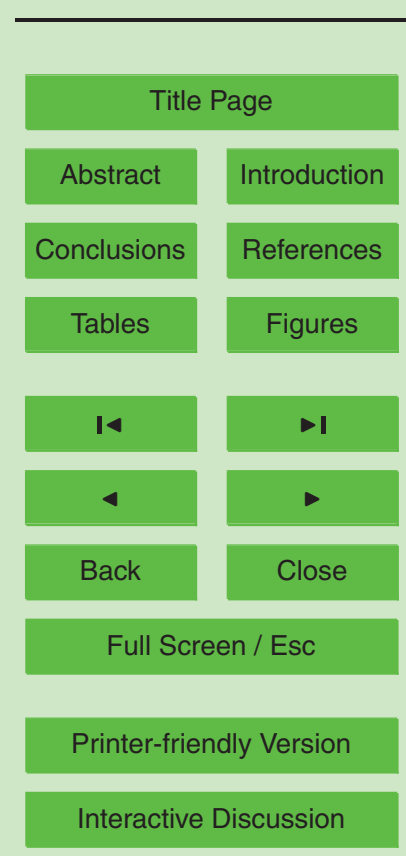


than triple the mean annual discharge having decreased in the winter months. In addition, these days have almost disappeared in autumn. Both March's outstanding value and February's second position are associated to the development of the two important high water events described, which took place at the beginning of this century.

The river's change of behaviour can be owed to different causes: one is that the first years of the 21st century seem to show a change in the yearly precipitation trend towards a certain rise, while the previous period 1980-2000 presented certain decreasing trend in the basin parts that are more susceptible of producing high water events in the Middle Ebro River (García Vera et al., 2002). The change in land use can play a sig10 nificant role as well in a double way. Firstly, the important rise of the irrigated surface in the basin, from 500000 ha in 1960 to 800000 ha in 2000 (OSE, 2008) has changed the morphology of the different floodplains, rising the vulnerability to floods in the lower areas, as well as modifying the fluvial territory. Secondly, agricultural rising demand of water has meant changes in the hydrological management that will be considered later. On the other hand, another effect of changes in land use is the abandonment of the less profitable agricultural land in mountainous areas, linked to the process of urbanisation experienced in Spain during the 60s and 70s. These old arable lands have been regained by forests, meaning lower river discharge due to the rise of interception (García Ruiz et al., 2001). This might have played an additional role in the recorded decrease of flood events during the 80 s and 90 s.

\subsection{Changes originated in hydrological management}

The recent changes in hydrological functioning and the trends observed cannot be explained solely by natural causes. There has been increasing human interventions in the hydrological management of the basin. Dams, especially large ones, have an outstanding role in modifying the hydrological functioning, both in normal situations and in extreme processes (Dynesius and Nilsson, 1992; Collier et al., 1998; Batalla et al., 2004; Martínez Santa-María and Fernández Yuste, 2006).

Currently 157 reservoirs are in use in the basin, their total storing capacity being

HESSD

6, 5937-5976, 2009

\section{Recent floods in the Middle Ebro River, Spain}

S. Domenech et al.

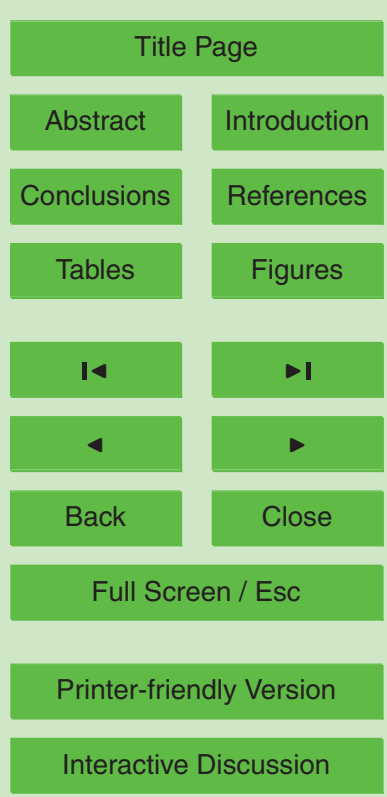

Interactive Discussion 
$8053 \mathrm{hm}^{3}$. The reservoir-stocking capacity up to Zaragoza is smaller, but nevertheless considerable: $2080 \mathrm{hm}^{3}$. Figure 9 shows the significant increase of the regulation up to Zaragoza due to two large reservoirs at the basin's headwaters: Reinosa reservoir $\left(540 \mathrm{hm}^{3}\right.$, which went into operation in 1945) and Yesa reservoir $\left(447 \mathrm{hm}^{3}\right.$, which 5 became fully operational in 1960 and will soon be enlarged up to $1066 \mathrm{hm}^{3}$ ). In the hydrological analysis of the Middle Ebro it has been observed that reservoirs have smoothed the Ebro River regime, removing the higher flows and alleviating the low water levels (Frutos et al., 2004). Winter discharges have decreased and the summer ones have increased. Most of the floods after 1960 have been modified, although by means of complex management manoeuvres of the different dams by the Confederación Hidrográfica del Ebro (CHE).

Indeed, during the last high water events the management carried out by the Decision Making Aid System (Sistema de Ayuda a la Decisión or SAD) from the SAIH real time data has been outstanding. This management combines water retentions in 15 some dams and reservoirs, controlled water withdrawals in others, in a gradual way so that the peaks of different tributaries do not coincide in the same river. This is a very difficult management due to the enormous variability of the factors involved in high water dynamics. But it has, however, had some effects reducing peak discharges and smoothing hydrographs.

20 The fact that the basin reservoirs have very low water levels at the end of summer, due to scarcity of precipitation and to the important consumption of irrigation crops, explains the remarkable reduction in autumn and first half of winter high water discharges in the Ebro axis. It can be stated that from October to January high waters are much retained due to reservoirs, which in addition use these events to store water for the 25 following summer. However, the regulating capacity is much lower from February to April, when the reservoirs tend to be almost full. This trend has been proved by some authors (López Moreno et al., 2002).

The hydrographs of the two most recent floods (2003 and 2007) have been normalized in Fig. 12, given the discharge peak of each event, in order to compare them with

HESSD

6, 5937-5976, 2009

\section{Recent floods in the Middle Ebro River, Spain}

S. Domenech et al.

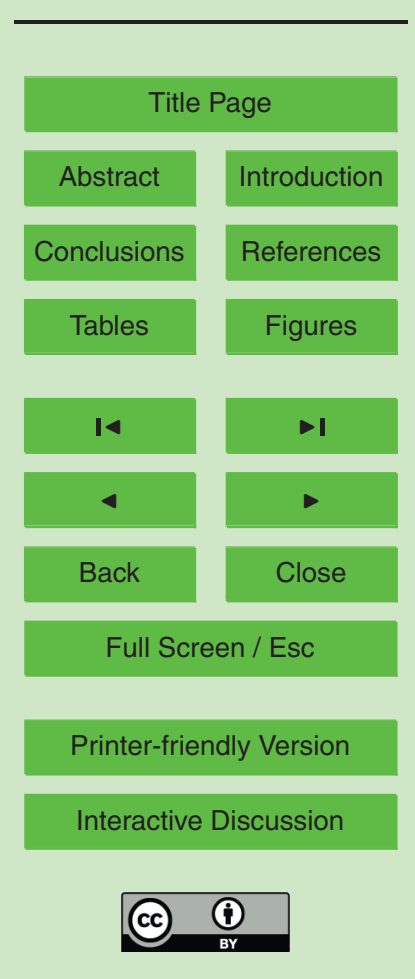


the hydrographs of two important discharge flood events $(1952,1961)$ previous to the management system through reservoirs. The following aspects can be highlighted: (i) both recent floods present hydrographs that look very much alike, almost superimposed, resulting from similar management; (ii) the hydrographs corresponding to the

5 old events show similar and very steeply rising curves; (iii) the descending curve of the 1961 hydrograph is the smoothest, most horizontal of the four curves due to the vast extension of the flood, which slowed down the process remarkably; (iv) however, the 1952 descending curve is very steep. It must be taken into account that at that moment there were practically no defences and that in a fast, medium water event the 10 water return process to the channel occurred very rapidly; ( $v$ ) the descending curves of the hydrographs of the 2003 and 2007 events are equidistant between those corresponding to 1952 (fast fall) and 1961 (slow fall).

Therefore, from these hydrographs we can draw the conclusion that reservoir management has an effect on rising curves (rendering them smoother and more horizontal, slowed-down process) and on peak discharges (alleviated), but it is not decisive on descending curves. The key factors in descending curves are flood extension and defence intervention.

\subsection{Floodplain management}

People have built defences along the Ebro River for centuries, at least since the Muslim 20 occupation in the 9th century, but these dikes were discontinuous and precarious. Up to 1960, the Middle Ebro floodplain had behaved as high water retention site with hardly any setbacks.

Since the large flood of 1961 the number of compacted earth dikes, ripraps, breakwaters, concrete walls and dredging have increased. The 1978, 1980 and 1981 floods caused a new massive defence construction period up to 1985, achieving the final channel stabilization. The lack of planning has caused certain conflicts and problems. Bank defences (ripraps at the concave banks) have been effective for socioeconomic interests, as they have eliminated channel mobility. However, the dikes built for flood

HESSD

6, 5937-5976, 2009

\section{Recent floods in the Middle Ebro River, Spain}

S. Domenech et al.

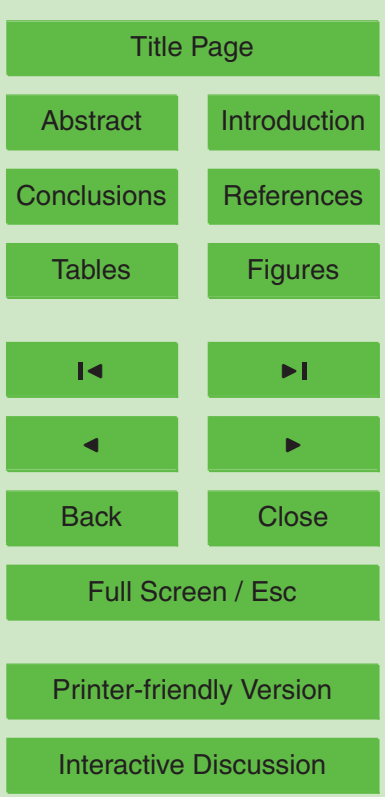


protection have failed due to their breaching or leaking in almost all floods, needing continuous maintenance work. While dikes have been instrumental in maintaining the channel morphology, they are not efficient to reduce floods. The February 2003 flood was much more extensive than expected, being produced due to the elevation caused 5 by channel defences. An estimated $83 \%$ of the floodplain was flooded and there were serious economic losses. During the April 2007 flood, $57 \%$ of the floodplain surface was flooded. Wyzga (1996) has observed similar processes in the Raba River.

Since the 2003 flood, an important debate has been established among river stakeholders, land managers, scientists and ecologists on floodplain management. The 10 Government of Aragón promoted the Environmental Plan of the Ebro River (2005, not been put into practice). In 2007, the Ebro Basin Authority (Confederación Hidrográfica del Ebro, or CHE as noted earlier) created a technical commission for environmental enhancement and risk mitigation in the floodplain of the Middle Ebro River, integrating it in the implementation of the 2000/60/EU Water Framework Directive, the 2007/60/EU 15 Floods Directive and the National Strategy for River Restoration (Spanish Ministry of the Environment). The technical commission is now (2009) evaluating three possible measures: (i) gates in dikes that could control 10-year flood areas with a capacity of $53 \mathrm{hm}^{3}$ upstream of Zaragoza; (ii) relief or two-stage flood channels to increase the drainage capacity in the six riskiest populated areas; (iii) removal of the dikes that were designed for 10-year return floods and installation of a new series of continuous dikes for 25-year floods.

The current river flood problem can be improved by the establishment of a wide, continuous and non-defended space, the "Fluvial Territory" (Ureña and Ollero, 2001; Ollero, 2007a) in which the river can overflow and its course can regain mobility. The 2007/60/UE Directive on the assessment and management of flood risks states that "whereas with a view to giving rivers more space, the maintenance and/or restoration of floodplains should be considered where possible".

As a result of the March-April 2007 flood and following the passing of the 2007/60/CE Directive a few months later, the Confederación Hidrográfica del Ebro has
HESSD

6, 5937-5976, 2009

\section{Recent floods in the Middle Ebro River, Spain}

S. Domenech et al.

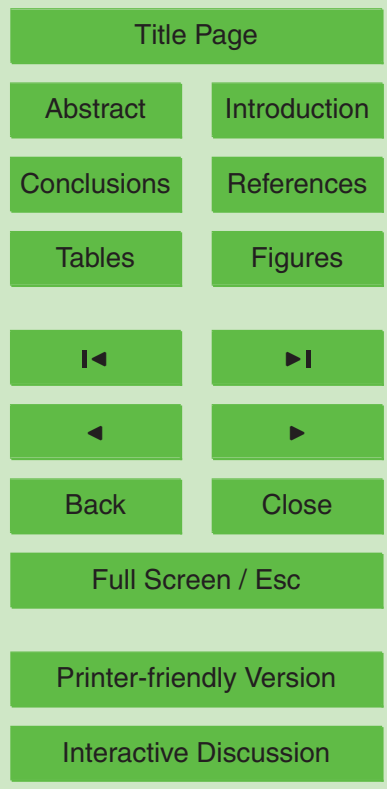


implemented a land information system (SITEbro) which can be checked in the Internet. In it there are detailed maps of floodable areas for different return periods, carried out with LIDAR technology.

\section{Conclusions}

5 It is obvious that there has been a change in the high water trends of the Middle Ebro not only affecting their seasonal nature but mainly their volume and frequency.

The fact that the basin reservoirs share both regulation and irrigation uses is reflected in the seasonal changes of high water events, there being a shift towards the end of winter and spring and clearly decreasing in autumn.

10 The turn of the century seems to consolidate a break of the discharge decreasing trend and especially of its maxima, observed since the late seventies. Among the causes of this change of trend, proven during the 2003 and 2007 floods, the atmospheric factors can be mentioned as well as others such as land uses and basin management.

15 The number of extraordinary high waters has been reduced thanks to the hydrological management implemented during such events, improved through real time control systems (SAD-SAIH). This has also caused a change in the shape of the Middle Ebro high water hydrographs, which responds to the water withdrawal manoeuvres in the basin, involving a decrease in the peak flows and a slowdown of the rising curve. This flood management is very useful in case of middle events, but it has proven limited when it comes to dealing with greater events.

Although high water management using reservoirs has been increasingly intense and efficient, the role of defences to avoid flooding has not been so effective. Other measures could be considered, such as defence removal or setback in order to create a river mobility area and improve the process alleviation.

The high water and flood events of a plain river system having an extensive basin surface are very complex processes. In every event it is extremely difficult to identify the

Recent floods in the Middle Ebro River, Spain

S. Domenech et al.

Title Page

Abstract

Introduction

Conclusions

Tables

References

Figures

14

$\rightarrow$

4

Back

Close

Full Screen / Esc

Printer-friendly Version

Interactive Discussion 
role of each hydrometeorological, anthropic and environmental factor, both on a basin and on a local scale. This paper gives an overview of the combined functioning of this set of factors, but it is necessary to develop this line of research in the future analyzing new events.

5 Acknowledgements. Thanks are due to the AEMET (State Meteorological Agency of Spain and the CHE (SAIH-Ebro and Servicio de Hidrología) for providing access to data necessary for this work. This general appreciation is personalized in J. R. Sánchez, I. Carrasco and A. Alvarez. Special thanks are also due to N. Prío for translating this text into English. Finally, the valuable guidance, comments and inputs of those who through this article's revision have contributed 10 ideas, thus enrichening it, are sincerely acknowledged.

\section{References}

Anquetin, S., Yates, E., Ducrocq, V., Samouillan, S., Chancibault, K., Davolio, S., Accadia, C., Casaioli, M., Mariani, S., Ficca, G., Gozzini, B., Pasi, F., Pasqui, M., Garcia, A., Martorell, M., Romero, R., and Chessa, P.: The 8 and 9 September 2002 flash flood event in France: a model intercomparison, Nat. Hazards Earth Syst. Sci., 5, 741-754, 2005, http://www.nat-hazards-earth-syst-sci.net/5/741/2005/.

Arduino, G., Reggiani, P., and Todini, E.: Recent advances in flood forecasting and flood risk assessment, Hydrol. Earth Syst. Sci., 9, 280-284, 2005, http://www.hydrol-earth-syst-sci.net/9/280/2005/.

Arnaud-Fassetta, G., Cossart, E., and Fort, M.: Hydrogeomorphic hazards and impact of manmade structures during the catastrophic flood of June 2000 in the Upper Guil catchment (Queyras, Southern French Alps), Geomorphology, 66, 41-67, 2005.

Ayala, F. J.: La inundación torrencial catastrófica del camping "Las Nieves" del 7 de Agosto de 1996 en el cono de deyección del Arás (Biescas, Pirineo Aragonés), in: Riesgos naturales, edited by: Ayala, F.J. and Olcina, J., Ariel, Barcelona, Spain, 889-912, 2002.

Bartholmes, J. and Todini, E.: Coupling meteorological and hydrological models for flood forecasting, Hydrol. Earth Syst. Sc., 9(4), 333-346, 2005.

Batalla, R. J., Gómez, C. M., and Kondolf, G. M.: Reservoir-induced hydrological changes in the Ebro river basin (NE Spain), J. Hydrol., 290, 117-136, 2004.
HESSD

6, 5937-5976, 2009

\section{Recent floods in the Middle Ebro River, Spain}

S. Domenech et al.

Title Page

Abstract

Introduction

Conclusions

References

Tables

Figures

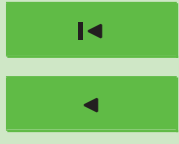

$\rightarrow$

Back

Close

Full Screen / Esc

Printer-friendly Version

Interactive Discussion 
Bates, B. C., Kundzewicz, Z. W., Wu, S., and Palutikof, J. P. (Eds.): Climate change and water, Intergovernmental Panel on Climate Change, Geneva, Technical Paper, 210 pp., 2008.

Bescós, A.: Las inundaciones en el río Arga: estudio hidrogeomorfológico, Ph.D. thesis, Departamento de Geografía, Universidad de Alcalá, Spain, 2003.

5 Bescós, A. and Camarasa, A. M.: La creciente ocupación antrópica del espacio inundable y el aumento de la vulnerabilidad en las poblaciones del bajo Arga (Navarra), Boletín de la Asociación de Geógrafos Españoles, 37, 101-117, 2004.

Cabezas, A., Comín, F. A., Beguería, S., and Trabucchi, M.: Hydrologic and landscape changes in the Middle Ebro River (NE Spain): implications for restoration and management, Hydrol. Earth Syst. Sci., 13, 1-12, 2009, http://www.hydrol-earth-syst-sci.net/13/1/2009/.

Carmona, P. and Ruiz Pérez, J.M.: Las inundaciones de los ríos Júcar y Turia, Serie Geográfica, 9, 49-69, 2000.

Christensen, N. S. and Lettenmaier, D. P.: A multimodel ensemble approach to assessment of 15 climate change impacts on the hydrology and water resources of the Colorado River Basin, Hydrol. Earth Syst. Sci., 11, 1417-1434, 2007, http://www.hydrol-earth-syst-sci.net/11/1417/2007/.

Collier, M., Webb, R. H., and Schmidt, J. C.: Dams and rivers: primer on the downstream effects of dams, 2nd ed., Diane Publ., Darby, PA, 94 pp., 1998.

Comisión Nacional de Protección Civil: Estudio de Inundaciones Históricas. Mapa de Riesgos Potenciales. Cuenca del Ebro. Dirección General de Obras Hidráulicas, Madrid, Spain, Techn. Rep., 1985.

Davy, L.: L'Ebre, étude hydrologique. Ph.D. thesis, Université de Lille, France, 803 pp., 1975.

Del Río, P.: Cadena operativa del sistema de análisis y predicción HIRLAM-INM, Servicio 25 de Modelización Numérica del Tiempo, Instituto Nacional de Meteorología, Madrid, Spain, Techn. Rep., 1998.

Del Valle, J.: Las intensas lluvias y riadas del 23 al 25 de octubre de 2000 en el SE de la cuenca del Ebro. Seguimiento y gestión mediante el S.A.I.H. de la C.H.E, in: La información climática como herramienta de gestión ambiental, edited by: Cuadrat, J. M., Vicente, S. M., and Saz, M. A, VII Reunión Nacional de Climatología, Universidad de Zaragoza, Albarracín, Spain, 93-98, 2002.

Díez Herrero, A., Laín, L., and Llorente, M.: Mapas de peligrosidad de avenidas e inundaciones. Métodos, experiencias y aplicación, Instituto Geológico y Minero de España, Madrid, Spain,

HESSD

6, 5937-5976, 2009

\section{Recent floods in the Middle Ebro River, Spain}

S. Domenech et al.

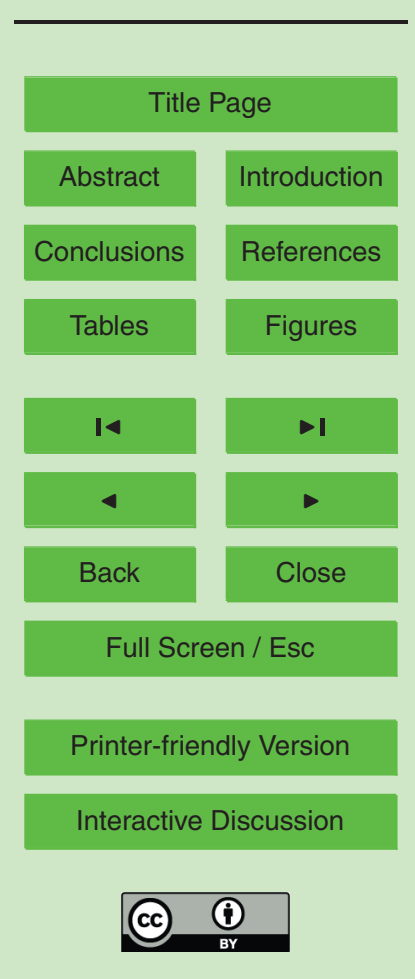


230 pp., 2006.

Díez Herrero, A., Laín, L., and Llorente, M.: Mapas de peligrosidad por avenidas e inundaciones. Guía metodológica para su elaboración, Instituto Geológico y Minero de España, Madrid, Spain, 190 pp., 2008.

5 Domenech, S.: Evaluación del riesgo de inundación del barranco Santa Bárbara-Depósitos ligado a precipitaciones extremas en Tauste (Zaragoza): caracteres y actuaciones. Techn. Rep., Universidad de Zaragoza, Spain, 2006.

Domenech, S.: Cartografía de peligrosidad de inundaciones: aplicación de una metodología al barranco Lierde (Villanúa, Huesca). Techn. Rep., Universidad de Zaragoza, Spain, 2008.

10 Dynesius, M. and Nilsson, C.: Fragmentation and flow regulation of river systems in the northern third of the world, Science, 266, 753-762, 1994.

Espejo, F.: Estudio de la fase atmosférica de situaciones de inundación en la Cuenca del Ebro: 1960-2007. Techn. Rep., Universidad de Zaragoza, Spain, 2007.

Espejo, F.: Cincuenta años de crecidas fluviales en la cuenca del Ebro: estudio de su fase atmosférica y clasificación, XXX Jornadas Científicas de la Asociación Meteorológica Española, Zaragoza, Spain, 2008a.

Espejo, F.: Hacia una tipología de inundaciones en la Cuenca del Ebro en función de sus causas atmosféricas, Geographicalia, 53, 73-100, 2008b.

Espejo, F.: Mayo de 2008, un mes destacable en el nordeste peninsular, Boletín de la Asociación Meteorológica Española, 21, 29-31, 2008c.

EEA (European Environment Agency): Climate change and water adaptation issues, Copenhagen, Denmark, Techn. Rep., 110 pp., 2007.

EEA (European Environment Agency): Water resources across Europe - confronting water scarcity and drought. Copenhagen, Denmark, EEA Report 2/2009, 55 p., 2009.

Frutos, L. M., Ollero, A., and Sánchez Fabre, M.: Caracterización del Ebro y su cuenca y variaciones en su comportamiento hidrológico, in: Alteración de los regímenes fluviales peninsulares, edited by: Gil Olcina, A. (Coord.), Fundación Cajamurcia, Murcia, Spain, 233-280, 2004.

García Ruiz, J. M., White, S., Martí-Bono, C., Valero, B., Errea, M. P., and Gómez Villar, A.: La catástrofe del barranco de Arás (Biescas, Pirineo Aragonés) y su contexto espacio-temporal, Instituto Pirenaico de Ecología, Zaragoza, Spain, 54 pp., 1996.

García Ruiz, J. M., Beguería, S., López Moreno, J. I., Lorente, A., and Seeger, M.: Los recursos hídricos superficiales del Pirineo aragonés y su evolución reciente, Geoforma Ediciones,
HESSD

6, 5937-5976, 2009

\section{Recent floods in the Middle Ebro River, Spain}

S. Domenech et al.

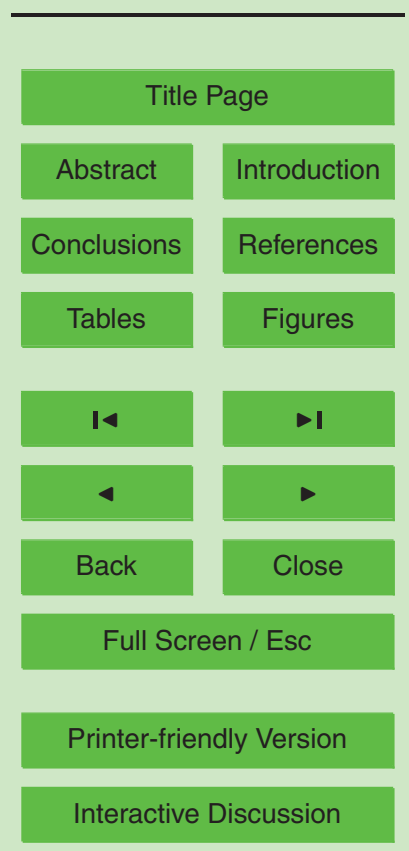


García Vera, M. A., Abaurrea, A., Asín, J., and Centelles, A.: Evolución de las precipitaciones en la cuenca del Ebro: caracterización espacial y análisis de las tendencias, in: La información climática como herramienta de gestión ambiental, edited by: Cuadrat, J. M., Vicente, S. M., and Saz, M. A., VII Reunión Nacional de Climatología, Universidad de Zaragoza, Albarracín, Spain, 99-108, 2002.

Gaume, E., Livet, M., Desbordes, M., and Villeneuve, J. P.: Hydrological analysis of the river Aude, France, flash flood on 12 and 13 Nov 1999, J. Hydrol., 286, 135-154, 2004.

Gil Olcina, A. (Coord.): Alteración de los regímenes fluviales peninsulares, Fundación Cajamurcia, Murcia, Spain, 2004.

Gouweleeuw, B. T., Thielen, J., Franchello, G., De Roo, A. P. J., and Buizza, R.: Flood forecasting using medium range-probabilistic weather prediction, Hydrol. Earth Syst. Sci., 9, 365-380, 2005, http://www.hydrol-earth-syst-sci.net/9/365/2005/.

15 Ibisate, A.: Las crecidas fluviales en el Zadorra: procesos, riesgos y propuestas de ordenación. Ph.D. thesis, Dpto. de Geografía, Prehistoria y Arqueología, Universidad del País Vasco, Vitoria-Gasteiz, Spain, 2004.

Ibisate, A., Ollero, A., and Ormaetxea, O.: Las inundaciones en la vertiente cantábrica del País Vasco en los últimos veinte años: principales eventos, consecuencias territoriales y sistemas

20 de prevención, Serie Geográfica, 9, 177-186, 2000.

IPCC: Climate change and water, Intergovernmental Panel on Climate Change, WMO-UNEP, Geneva, Techn. Rep., 210 pp., 2008.

Kobold, M. and Sušelj, K.: Precipitation forecasts and their uncertainty as input into hydrological models, Hydrol. Earth Syst. Sci., 9, 322-332, 2005,

25 http://www.hydrol-earth-syst-sci.net/9/322/2005/.

Linares, A.: El SAlH-Ebro: un sistema de información y ayuda a la decisión para la previsión de avenidas y gestión de los recursos hidráulicos de la cuenca hidrográfica del río Ebro (España), V Congreso Ibérico Gestión y Planificación del Agua, Faro, Portugal, 2006.

López Moreno, J. I., Beguería, S., and García Ruíz, J. M.: Influence of the Yesa Reservoir on floods of the Aragón River, central Spanish Pyrenees, Hydrol. Earth Syst. Sci., 6, 753-762, 2002,

http://www.hydrol-earth-syst-sci.net/6/753/2002/.

Martínez Santa-María, C. and Fernández Yuste, J. A.: Índices de alteración hidrológica en

\section{Recent floods in the Middle Ebro River, Spain}

S. Domenech et al.

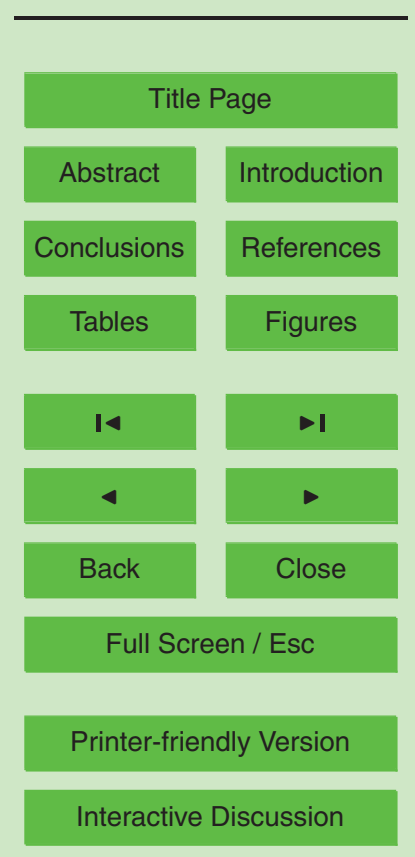


ecosistemas fluviales, CEDEX, Madrid, 178 pp., 2006.

Milly, P. C. D., Dunne, K. A., and Vecchia, A. V.: Global pattern of trends in streamflow and water availability in a changing climate. Nature, 438, 347-350, 2005.

Norbiato, D., Borga, M., Sangati, M., and Zanon, F.: Regional frequency analysis of extreme 5 precipitation in the eastern Italian Alps and the August 29, 2003 flash flood, J. Hydrol., 345, 149-166, 2007.

Ogden, F. L., Sharif, H. O., Senarath, S. U. S., Smith, J. A., Baeck, M. L., and Richardson, J. R.: Hydrologic analysis of the Fort Collins, Colorado, flash flood of 1997, J. Hydrol., 228, 82-100, 2000.

10 Ollero, A.: Los meandros libres del Ebro medio (Logroño-La Zaida): geomorfología fluvial, ecogeografía y riesgos. Ph.D. thesis. Dpto. de Geografía y Ordenación del Territorio, Universidad de Zaragoza, Spain, 1992.

Ollero, A.: Las riberas del Ebro medio: diagnosis y ordenación de un paisaje fluvial amenazado, II Congreso Ibérico sobre Planificación y Gestión de Aguas, Oporto, Portugal, 139-150, 152000.

Ollero, A.: Territorio fluvial. Diagnóstico y propuesta para la gestión ambiental y de riesgos en el Ebro y los cursos bajos de sus afluentes, Bakeaz y Fundación Nueva Cultura del Agua, Bilbao, Spain, 255 pp., 2007a.

Ollero, A.: La avenida del río Ebro en 2003. Medidas para la reducción de daños. Gestión de la ribera, in: Ingenierí a fluvial. Aspectos técnicos y medioambientales, edited by: Martín Vide, J. P., Centro Internacional de Métodos Numéricos en Ingeniería, Barcelona, Spain, 247-265, 2007b.

Ollero, A., Sánchez Fabre, M., and Del Valle, J.: Problemática actual del corredor ribereño del Ebro aragonés en su curso de meandros libres, in: Geografía Física de Aragón. Aspectos generales y temáticos, edited by: Peña, J. L., Longares, L. A., and Sánchez Fabre, M., Universidad de Zaragoza, Spain, 253-263, 2004a.

Ollero, A., Pellicer, F., and Sánchez Fabre, M.: La crecida de febrero de 2003 en el curso medio del Ebro: análisis de su evolución espacio-temporal, in: Aportaciones geográficas en homenaje al Profesor Antonio Higueras Arnal, edited by: Faus, M. C. (Coord.), Universidad de Zaragoza, Spain, 143-155, 2004b.

OSE: Agua y sostenibilidad: funcionalidad de las cuencas, Observatorio de la Sostenibilidad en España, Ministerio de Medio Ambiente y Medio Rural y Marino, Fundación Biodiversidad y Universidad de Alcalá, Spain, 203 pp., 2008.
HESSD

6, 5937-5976, 2009

\section{Recent floods in the Middle Ebro River, Spain}

S. Domenech et al.

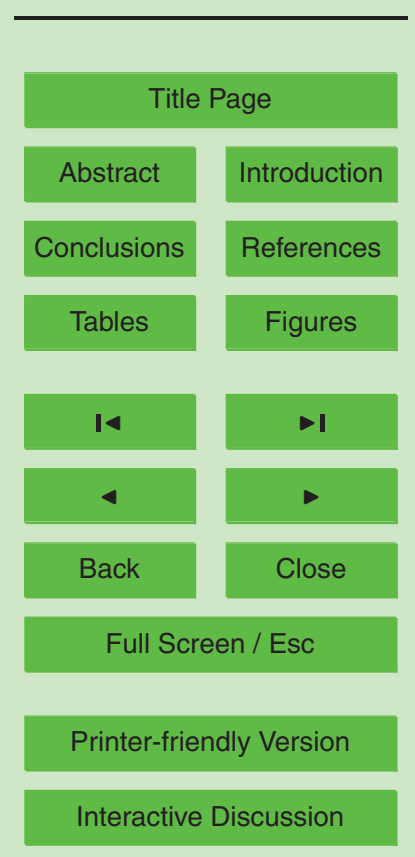

Interactive Discussion 
Rabuffetti, D. and Milelli, M.: The hydro-meteorological chain in Piemonte region, North Western Italy - analysis of the HYDROPTIMET test cases, Nat. Hazards Earth Syst. Sci., 5, 845-852, 2005, http://www.nat-hazards-earth-syst-sci.net/5/845/2005/.

5 Rabuffetti, D. and Barbero, S.: Operational hydro-meteorological warning and real-time flood forecasting: the Piemonte Region case study, Hydrol. Earth Syst. Sci., 9, 457-466, 2005, http://www.hydrol-earth-syst-sci.net/9/457/2005/.

Ratto, S., Bonetto, F., and Comoglio, C.: The October 2000 flooding in Valle d'Aosta (Italy): event description and land planning measures for the risk mitigation, Int. J. River Basin Manag., 1(1), 105-116, 2003.

Rebora, N., Ferraris, L., von Hardenberg, J., and Provenzale, A.: Rainfall downscaling and flood forecasting: a case study in the Mediterranean area, Nat. Hazards Earth Syst. Sci., 6, 611-619, 2006, http://www.nat-hazards-earth-syst-sci.net/6/611/2006/.

Requena, R., Espejo, F., Desentre, A., and Álvarez, E.: Apoyo meteorológico a la gestión hidrológica de las crecidas del Río Ebro de marzo y abril de 2007, Boletín de la Asociación Meteorológica Española, 20, 20-23, 2008.

Riosalido, R., Ferraz, J., Álvarez, E., Cansado, A., Martín, F., Elizaga, F., Martín, A., Camacho, J. L., and Mestre, A.: Estudio meteorológico de la situación del 7 de agosto de 1996 20 (Biescas), Instituto Nacional de Meteorología, Madrid, 90 pp., 1998.

Romero, A. and Maurandi, A.: Las inundaciones en la cuenca del Segura en las dos últimas décadas del siglo XX. Actuaciones de prevención, Serie Geográfica, 9, 93-120, 2000.

Storch, H. V. and Zwiers, F. W.: Statistical Analysis in Climate Research. Cambridge University Press, UK, 1999.

Uppala, S. M. (Coord.): The ERA-40 reanalysis, Q. J. Roy. Meteor. Soc., 131, 2961-3012, 2005.

Ureña, J. M. and Ollero, A.: Fluvial landscapes, catchment administration and land-use planning: experience based on two rivers in Spain, Landscape Res., 26(3), 225-243, 2001.

Vallejo, I.: Las inundaciones en la cuenca del Guadalquivir, Serie Geográfica, 9, 133-149, 2000.

Wyzga, B.: Changes in the magnitude and transformation of flood waves subsequent to the channelization of the Raba River, Polish Carpathians, Earth Surf. Proc. Land., 21(8), 749763, 1996.

\section{HESSD}

6, 5937-5976, 2009

\section{Recent floods in the Middle Ebro River, Spain}

S. Domenech et al.

Title Page

Abstract

Introduction

Conclusions

References

Tables

Figures

14

$\rightarrow$

Back

Close

Full Screen / Esc

Printer-friendly Version

Interactive Discussion 


\section{HESSD}

6, 5937-5976, 2009

\section{Recent floods in the Middle Ebro River, Spain}

Table 1. Instant discharge maxima $\left(\mathrm{m}^{3} / \mathrm{s}\right)$ and return periods $(\mathrm{yr})$ of the Ebro River extraordinary floods from 1950.

\begin{tabular}{lllll}
\hline Flood event & $\begin{array}{l}\text { Castejón } \\
\left(\text { Basin area 25 } 194 \mathrm{~km}^{2}\right)\end{array}$ & Return period & $\begin{array}{l}\text { Zaragoza } \\
\left(\text { Basin area } 40434 \mathrm{~km}^{2}\right)\end{array}$ & Return period \\
\hline Feb 1952 & 3140 & 8.6 & 3260 & 20.7 \\
May 1956 & 2960 & 6.8 & 2744 & 9.0 \\
Dec 1959 & 2810 & 5.5 & 2790 & 9.7 \\
Jan 1961 & 4950 & 96.2 & 4130 & 84.7 \\
Nov 1961 & 3200 & 9.3 & 2570 & 6.8 \\
Nov 1966 & 4050 & 28.9 & 3154 & 17.5 \\
Jan 1968 & 3012 & 7.3 & 2494 & 6.0 \\
Jun 1977 & 2628 & 4.3 & 2437 & 5.5 \\
Feb 1978 & 3375 & 11.8 & 3154 & 17.5 \\
Jan 1979 & 2770 & 5.3 & 2581 & 6.9 \\
Dec 1980 & 3191 & 9.2 & 2500 & 6.1 \\
Jan 1981 & 2676 & 4.6 & 2525 & 13.3 \\
Feb 2003 & 3320 & 10.9 & 2988 & 4.2 \\
Mar-Apr 2007 & 2826 & 5.6 & 2282 & \\
\hline
\end{tabular}

S. Domenech et al.

Title Page

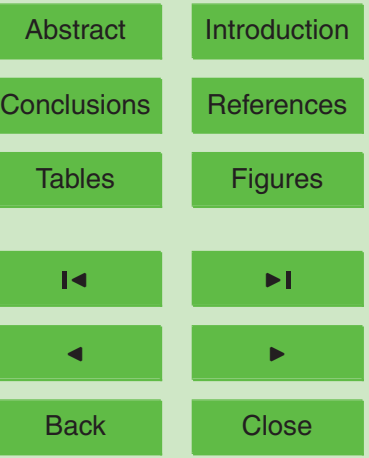

Full Screen / Esc

Printer-friendly Version

Interactive Discussion 


\section{HESSD}

6, 5937-5976, 2009

\section{Recent floods in the Middle Ebro River, Spain}

Table 2. Trends in the maximum annual and seasonal discharges at Zaragoza gauging station according to the statistical analysis using Spearman's rho bivariate non-parametric correlation for different periods. The statistically significant correlations appear in bold type and the $99 \%$ significant correlations in italics.

\begin{tabular}{|c|c|c|c|c|c|c|c|c|c|c|}
\hline Period & $\begin{array}{l}\text { Year } \\
\text { corr. }\end{array}$ & sign. & $\begin{array}{l}\text { Autumn } \\
\text { corr. }\end{array}$ & sign. & $\begin{array}{l}\text { Winter } \\
\text { corr. }\end{array}$ & sign. & $\begin{array}{l}\text { SPRING } \\
\text { corr. }\end{array}$ & sign. & $\begin{array}{l}\text { Summer } \\
\text { corr. }\end{array}$ & sign. \\
\hline $45 / 46-07 / 08$ & -0.397 & 0.000 & -0.171 & 0.181 & -0.376 & 0.002 & -0.221 & 0.081 & -0.215 & 0.090 \\
\hline $60 / 61-07 / 08$ & -0.491 & 0.000 & -0.262 & 0.072 & -0.485 & 0.000 & -0.262 & 0.072 & -0.315 & 0.029 \\
\hline 98/99-07/08 & +0.406 & 0.244 & -0.661 & 0.010 & -0.261 & 0.467 & +0.552 & 0.098 & +0.273 & 0.446 \\
\hline
\end{tabular}

S. Domenech et al.

Title Page

Abstract

Introduction

Conclusions

References

Tables

Figures

14

$\rightarrow 1$

4

Back

Close

Full Screen / Esc

Printer-friendly Version

Interactive Discussion 


\section{HESSD}

6, 5937-5976, 2009

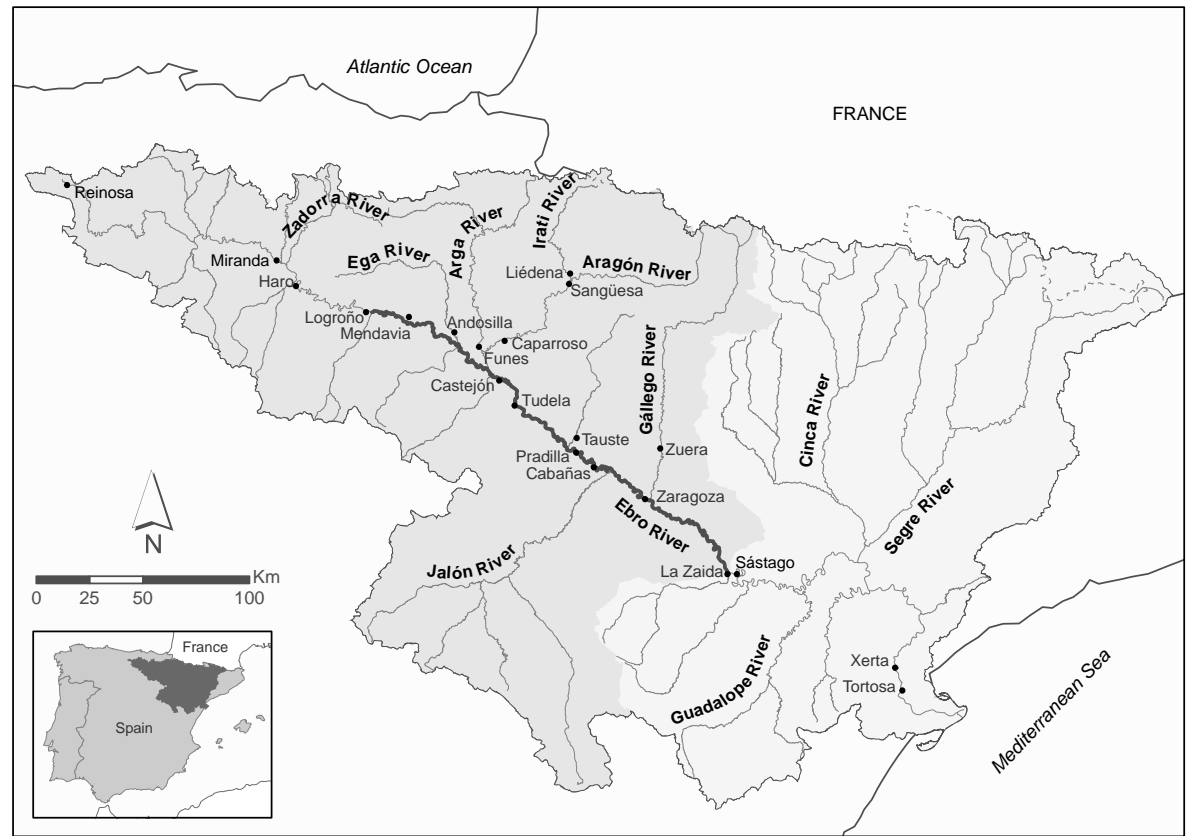

\section{Recent floods in the Middle Ebro River, Spain}

S. Domenech et al.

Title Page

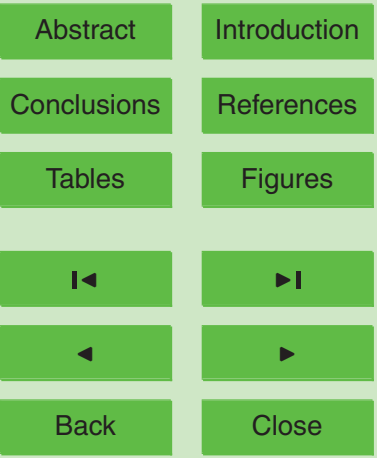

Full Screen / Esc

Fig. 1. The free-meandering Middle Ebro River in the context of the Ebro Basin.

Printer-friendly Version

Interactive Discussion 


\section{HESSD}

6, 5937-5976, 2009

\section{Recent floods in the Middle Ebro River, Spain}
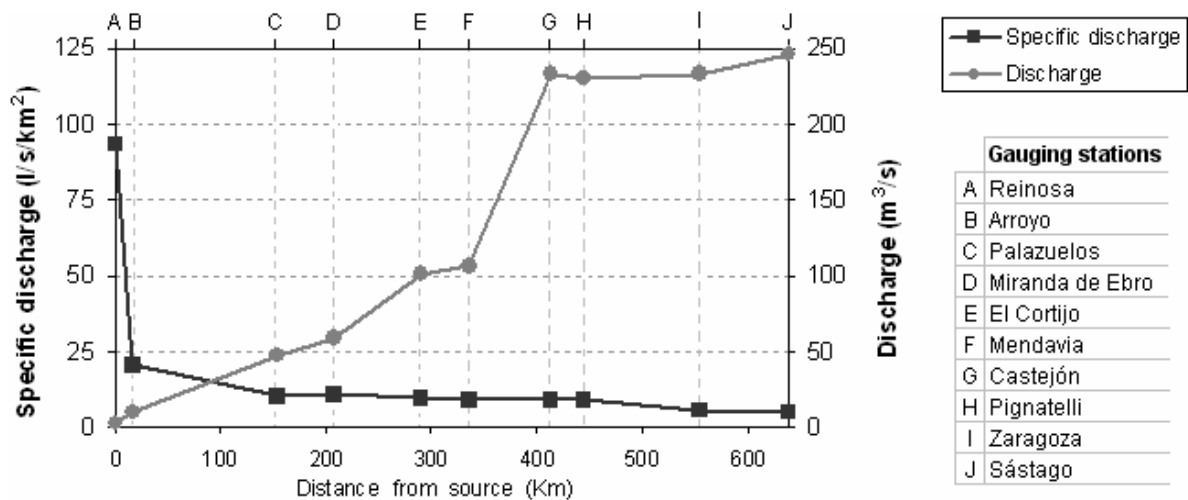

Fig. 2. Ebro River discharge and specific discharge from the source to Sástago at diverse gauging stations.

\section{S. Domenech et al.}

\section{Title Page}

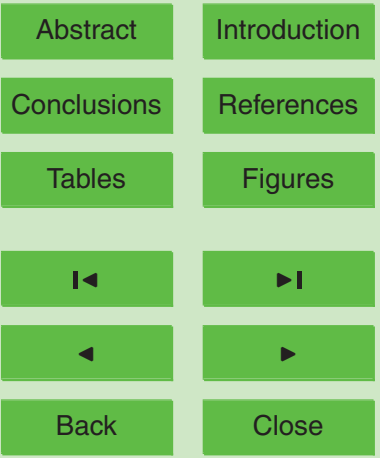

Full Screen / Esc

Printer-friendly Version

Interactive Discussion 


\section{HESSD}

6, 5937-5976, 2009

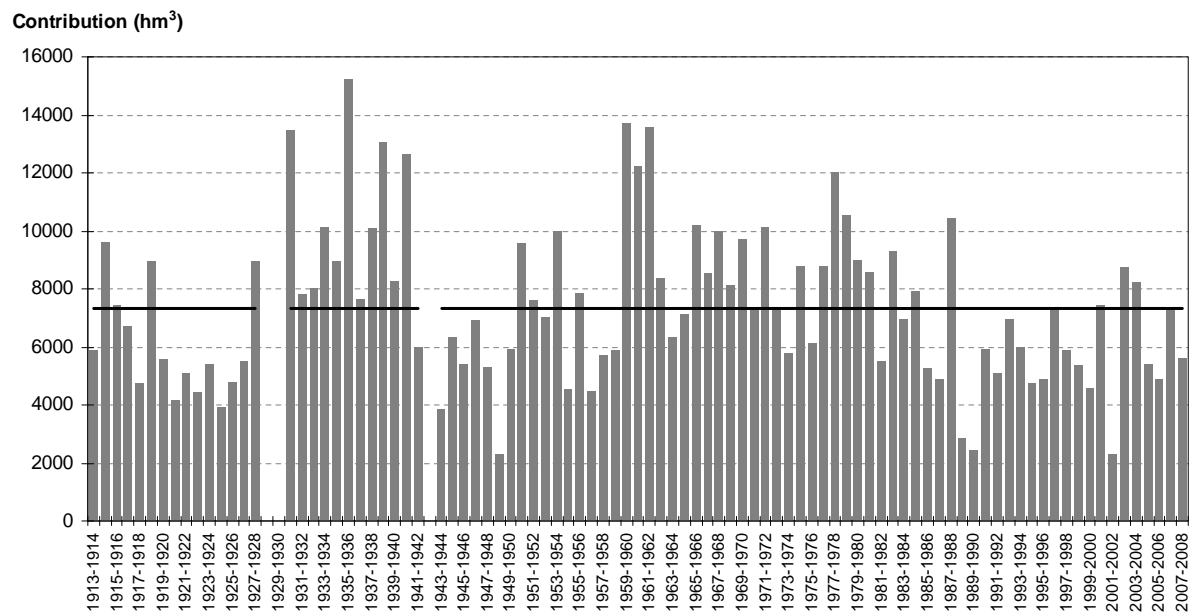

\section{Recent floods in the Middle Ebro River, Spain}

S. Domenech et al.

Title Page

Abstract

Introduction

Conclusions

References

Tables

Figures

14

4

Full Screen / Esc

Printer-friendly Version

Interactive Discussion 


\section{HESSD}

6, 5937-5976, 2009
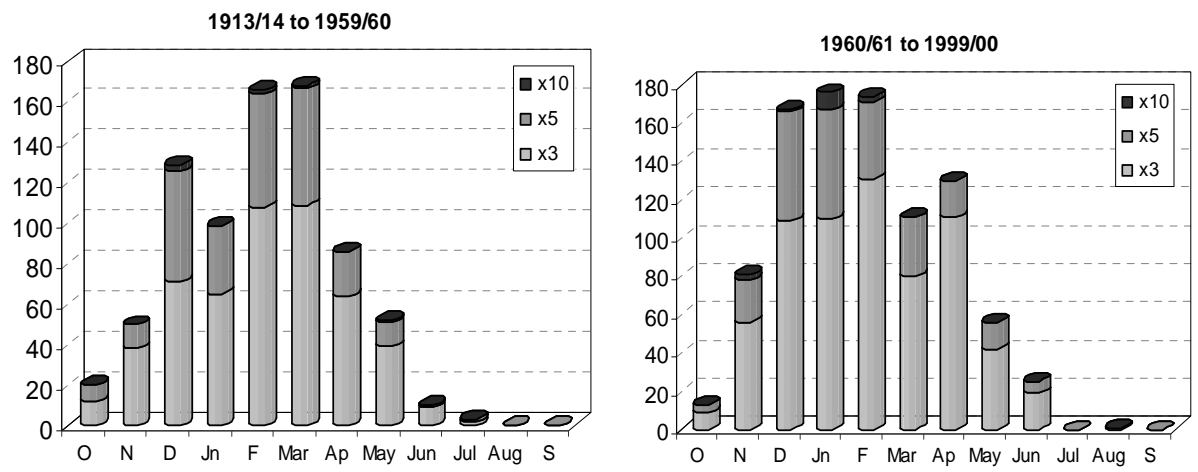

\section{Recent floods in the Middle Ebro River, Spain}

\section{S. Domenech et al.}

\section{Title Page}

Abstract

Introduction

$2000 / 01$ to $2007 / 08$

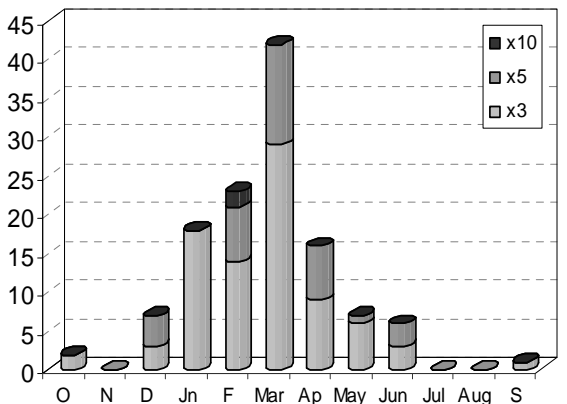

Conclusions

References

Tables

Figures

14

$\rightarrow$

4

Back

Close

\section{Full Screen / Esc}

Fig. 4. Number of days in which the daily mean discharge of the Ebro River multiplied by three, five and ten the mean annual discharge at Zaragoza gauging station.

Printer-friendly Version

Interactive Discussion 


\section{HESSD}
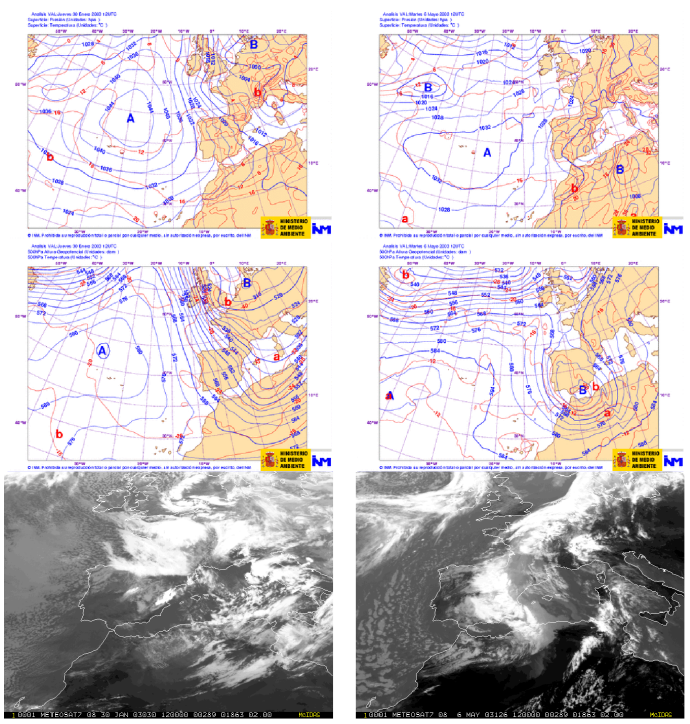

\section{6, 5937-5976, 2009}

\section{Recent floods in the Middle Ebro River, Spain}

\section{S. Domenech et al.}

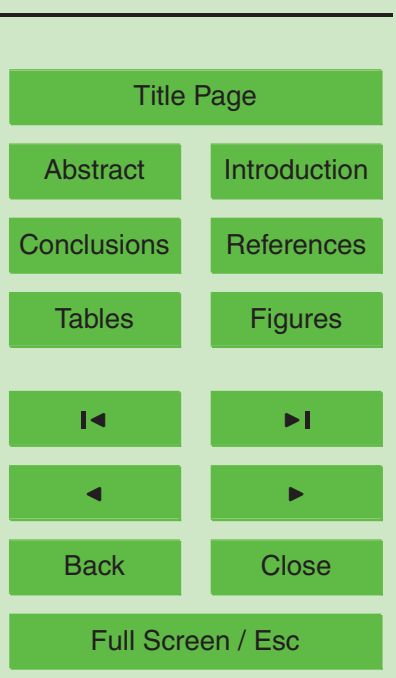

Printer-friendly Version

Interactive Discussion 


\section{HESSD}

6, 5937-5976, 2009

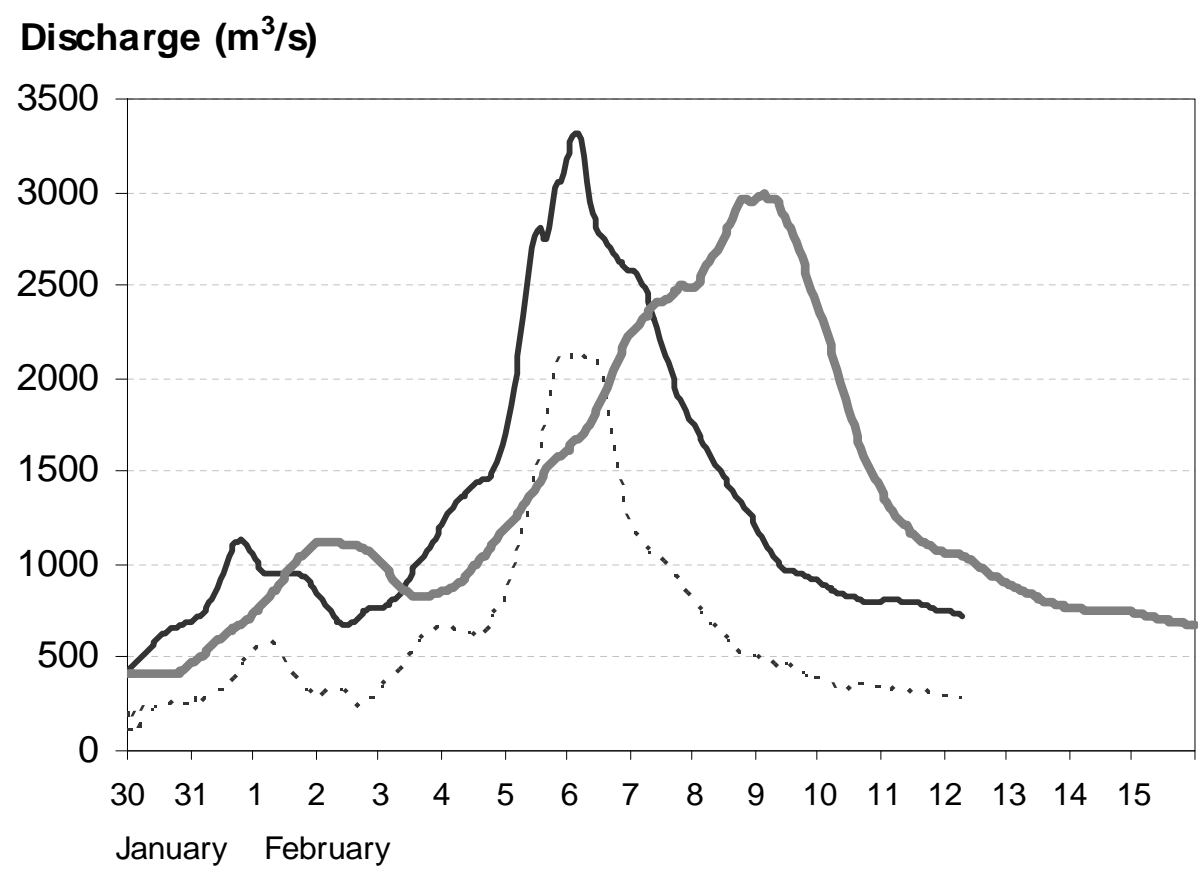

\section{Recent floods in the Middle Ebro River, Spain}

S. Domenech et al.

Title Page

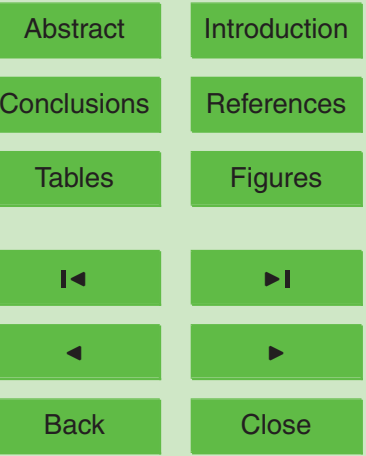

Full Screen / Esc

Fig. 6. Hydrograph of the February 2003 flood event.

Printer-friendly Version

Interactive Discussion 


\section{HESSD}

6, 5937-5976, 2009

\section{Recent floods in the Middle Ebro River, Spain}

S. Domenech et al.

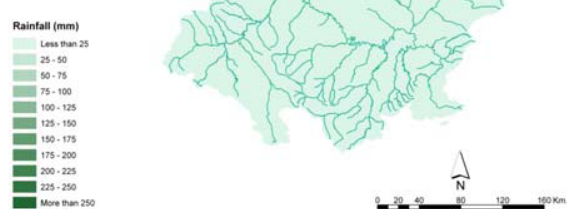

Title Page

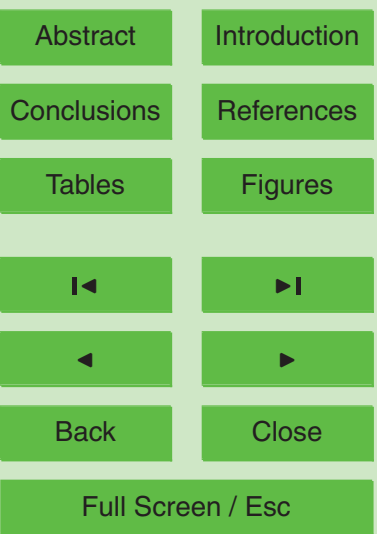

Printer-friendly Version

Interactive Discussion 


\section{HESSD}

6, 5937-5976, 2009

\section{Recent floods in the Middle Ebro River, Spain}

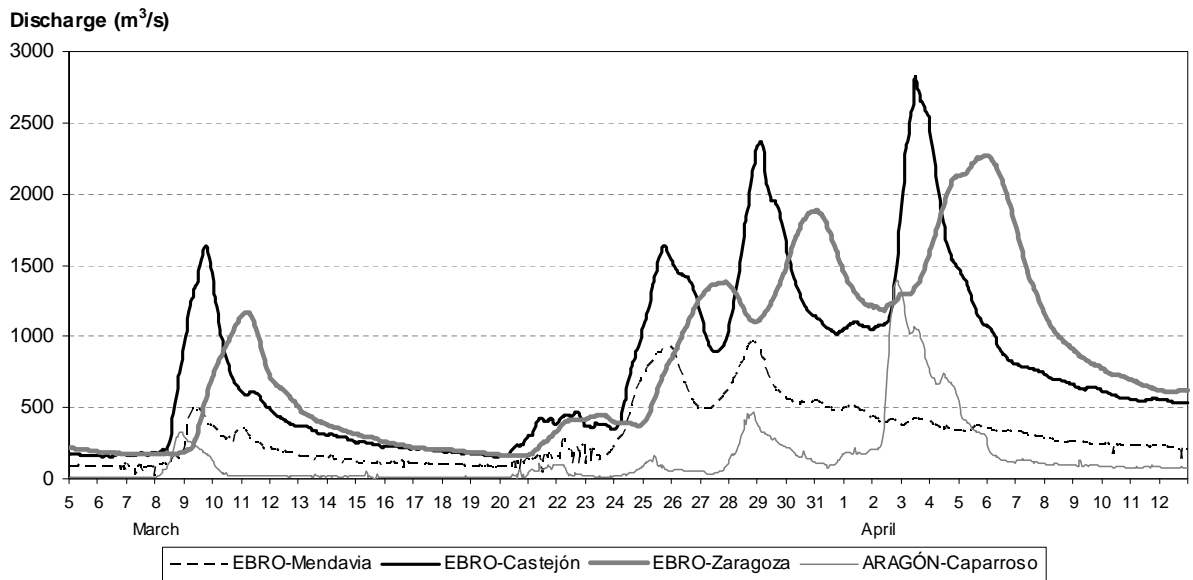

S. Domenech et al.

Title Page

Abstract

Introduction

Conclusions

References

Tables

Figures

14

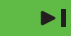

4

Back

Full Screen / Esc

Printer-friendly Version

Interactive Discussion 


\section{HESSD}

6, 5937-5976, 2009

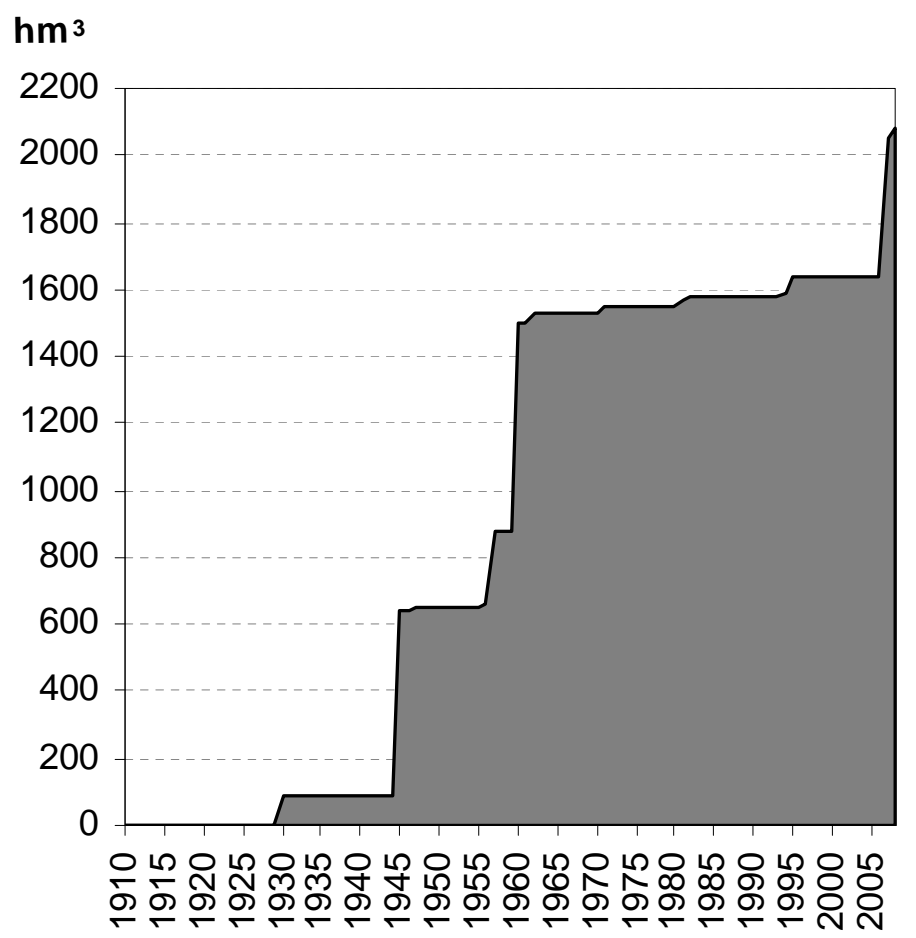

\section{Recent floods in the Middle Ebro River, Spain}

S. Domenech et al.

Title Page

Abstract

Introduction

Conclusions

References

Tables

Figures

14

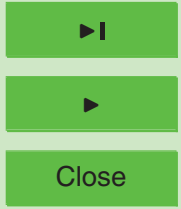

Back

Close

\section{Full Screen / Esc}

Printer-friendly Version

Interactive Discussion 


\section{HESSD}

6, 5937-5976, 2009

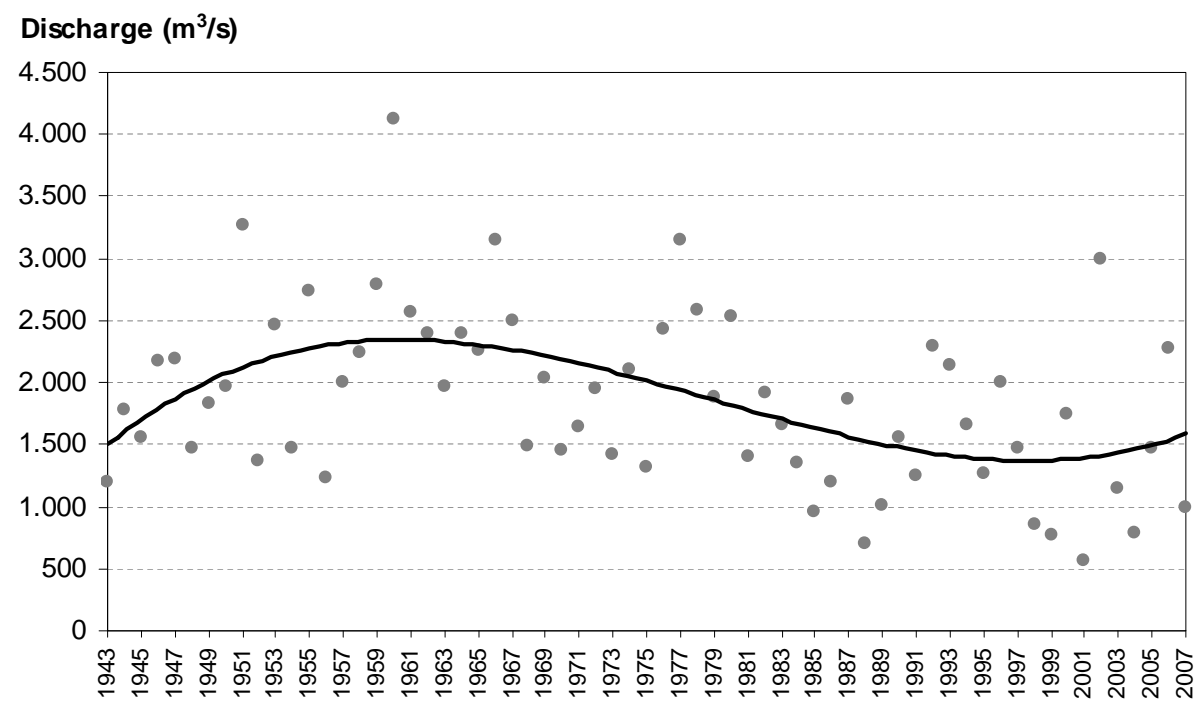

\section{Recent floods in the Middle Ebro River, Spain}

S. Domenech et al.

Title Page

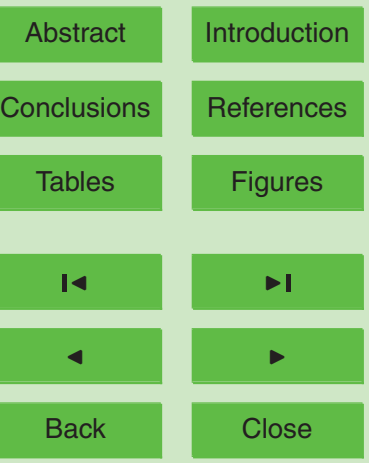

Fig. 10. Annual instant discharge maxima of the Ebro River in Zaragoza gauging station (1943-

Full Screen / Esc

Printer-friendly Version

Interactive Discussion 


\section{HESSD}

6, 5937-5976, 2009

\section{Recent floods in the Middle Ebro River, Spain}

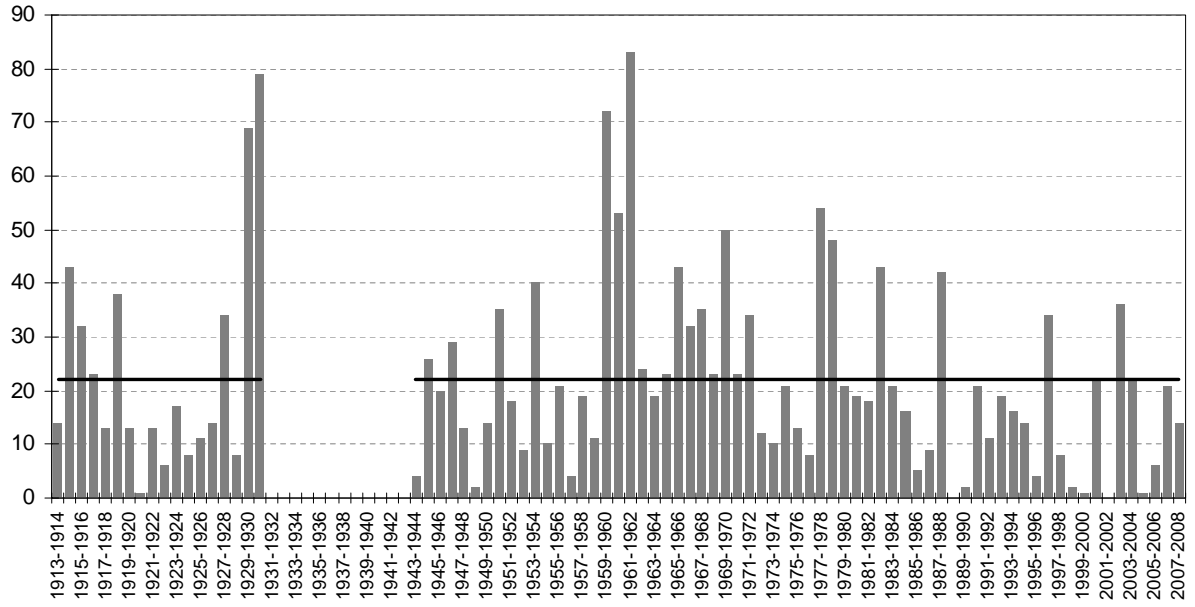

Fig. 11. Number of days per year in which the discharge multiplies by three the mean annual discharge at Zaragoza gauging station.

Title Page

Abstract

Introduction

Conclusions

References

Tables

Figures

14

4

Back

Close

Full Screen / Esc

Printer-friendly Version

Interactive Discussion 


\section{HESSD}

6, 5937-5976, 2009

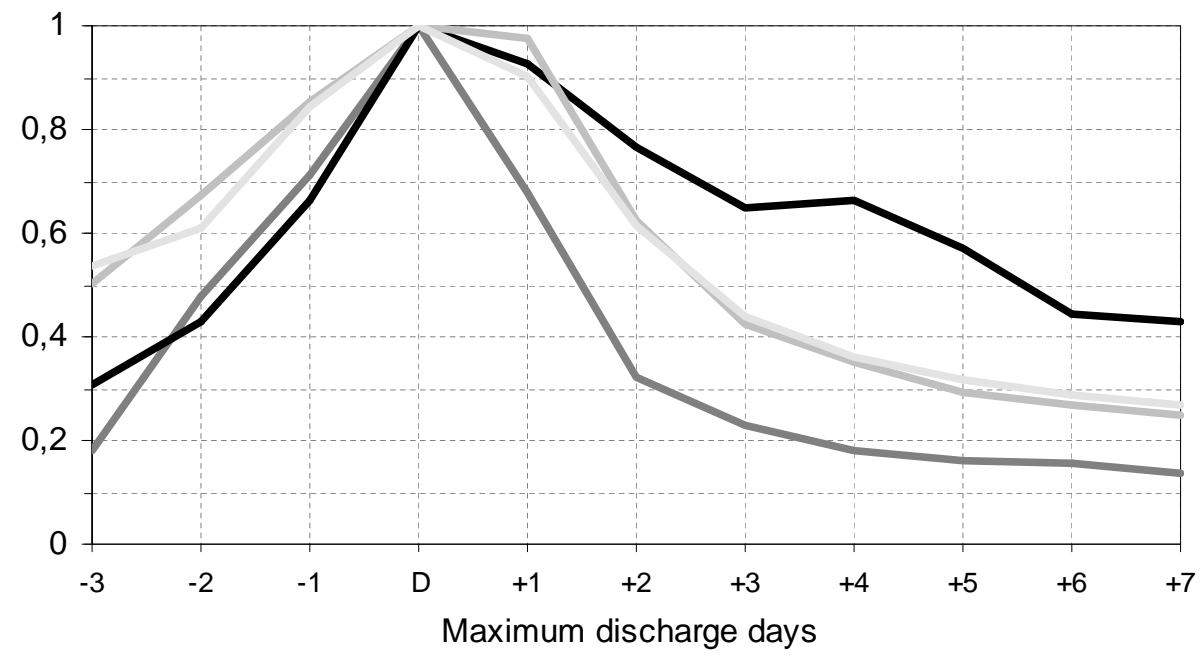

\section{Recent floods in the Middle Ebro River,} Spain

S. Domenech et al.

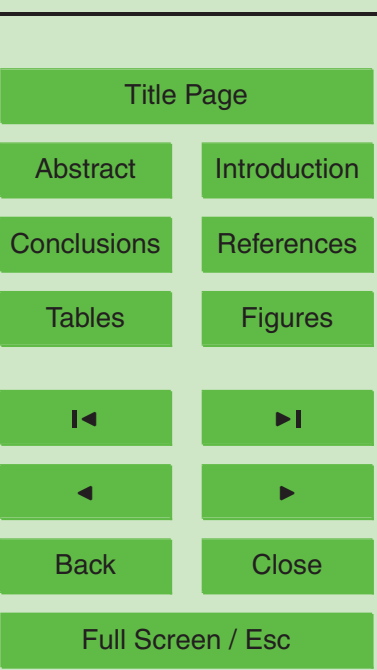

Printer-friendly Version

Interactive Discussion 